Florida International University FIU Digital Commons

7-13-2010

\title{
Misinterpreted experiences : the tension between imagination and divine revelation in early 19th century Anglo American Gothic fiction
}

Diana I. Dabek

Florida International University

DOI: $10.25148 /$ etd.FI14061582

Follow this and additional works at: https://digitalcommons.fiu.edu/etd

Part of the Literature in English, North America Commons

\section{Recommended Citation}

Dabek, Diana I., "Misinterpreted experiences : the tension between imagination and divine revelation in early 19th century Anglo American Gothic fiction" (2010). FIU Electronic Theses and Dissertations. 2649.

https://digitalcommons.fiu.edu/etd/2649 
FLORIDA INTERNATIONAL UNIVERSITY

Miami, Florida

MISINTERPRETED EXPERIENCES: THE TENSION BETWEEN IMAGINATION AND DIVINE REVELATION IN EARLY 19TH CENTURY ANGLO AMERICAN GOTHIC FICTION

A thesis submitted in partial fulfillment of the

requirements for the degree of

MASTER OF ARTS

in

ENGLISH

by

Diana I. Dabek

2010 
To: Dean Kenneth Furton

College of Arts and Sciences

This thesis, written by Diana I. Dabek, and entitled Misinterpreted Experiences: The Tension between Imagination and Divine Revelation in early $19^{\text {th }}$ century Anglo American Gothic Fiction, having been approved in respect to style and intellectual content, is referred to you for judgment.

We have read this thesis and recommend that it be approved.

Andrew Strycharski

Yvette Piggush

Bruce Harvey, Major Professor

Date of Defense: July 13, 2010

The thesis of Diana I. Dabek is approved.

Dean Kenneth Furton College of Arts and Sciences

Interim Dean Kevin O'Shea University Graduate School

Florida International University, 2010 


\section{DEDICATION}

This thesis is dedicated to my cheerleaders. I owe eternal gratefulness to my family for their enduring patience and unconditional support throughout the years. The success of this project is largely attributed to their words of encouragement and their full trust in my abilities to pursue my goals. 


\section{ACKNOWLEDGMENTS}

It has been a pleasure working with a thesis committee who from the very beginning showed great interest in this project. I wish to thank Dr. Yvette Piggush and Dr. Andrew Strycharski for their guidance throughout this process. Without their stimulating feedback the completion of this thesis would not have been possible.

Finally, I would like to extend my gratitude to my major professor, Dr. Bruce Harvey, who has made available his support in a number of ways. His positive attitude and willingness to help have made my graduate experience memorable. Frequent conversations with Dr. Harvey have instilled in me a great sense of respect for the academe. As a scholar, I have found his passion for literature to be both inspiring and infectious. Words fall short from expressing my appreciation for the time and energy that Dr. Harvey has invested in this thesis. His enthusiasm regarding this project as well as my future academic endeavors truly make him an admirable mentor. 


\section{ABSTRACT OF THE THESIS \\ MISINTERPRETED EXPERIENCES: THE TENSION BETWEEN IMAGINATION \\ AND DIVINE REVELATION IN EARLY 19TH CENTURY ANGLO AMERICAN \\ GOTHIC FICTION \\ by}

Diana I. Dabek

Florida International University, 2010

Miami, Florida

Professor Bruce Harvey, Major Professor

The purpose of this study was to analyze the ways in which $19^{\text {th }}$ century Gothic fiction novelists Charles Brockden Brow and James Hogg explore the themes of religious enthusiasm and divine revelation. A close look at these texts reveals a common interest in the tension between the imagination and reality. By analyzing the philosophical and theological roots of these issues it becomes clear that Wieland and Confessions of a Justified Sinner mirror the anxieties of $19^{\text {th }}$ century Anglo American culture. Questions regarding voice and authority, the importance of testimony, and religious seduction are common to both novels. I maintain that these authors comment on the obscure nature of human rationale by presenting readers with narrators that exhibit traits of delusion and spiritual awakening. 


\section{TABLE OF CONTENTS}

CHAPTER

PAGE

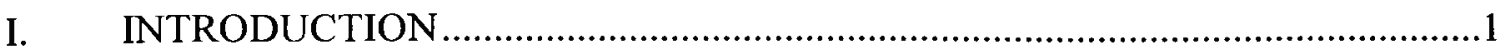

II. PERPLEXING PERCEPTIONS IN THE GOTHIC TRADITION .........................

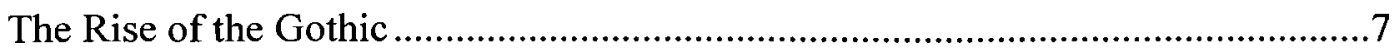

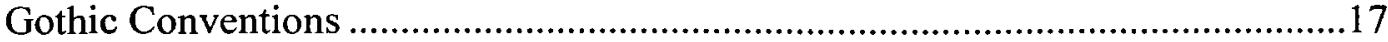

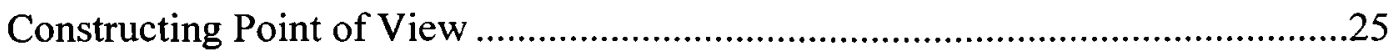

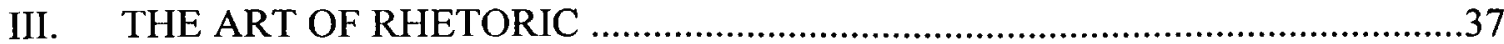

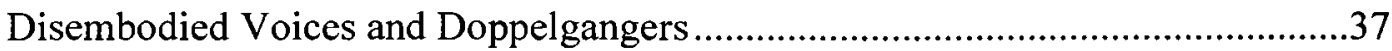

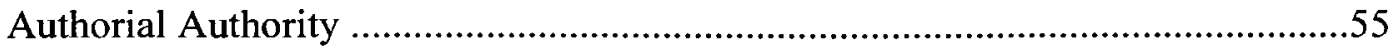

Testimonies and Confessions ...............................................................................

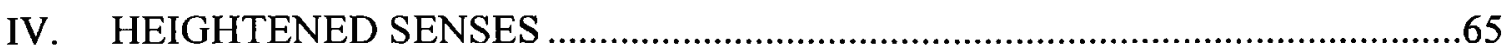

The Tension between Religious Enthusiasm and Divine Revelation ......................65

Supernatural Occurrences and Misinterpreted Experiences ...................................75

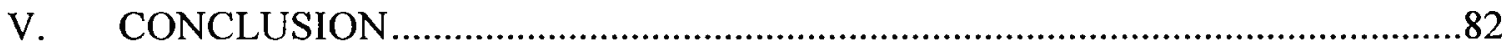

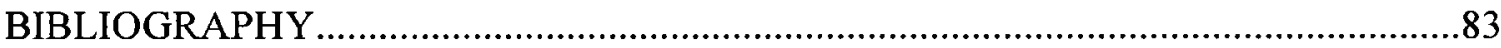




\section{INTRODUCTION}

Revered for its uncouth style and unsettling themes, the Gothic novel has long been the focus of literary studies. This amalgamation of romance and horror provides contemporary readers with a window into $19^{\text {th }}$ century Anglo-American culture.

Emblematic of the social and political turmoil of its era, the Gothic novel became an avenue through which writers could explore issues pertaining to theology and philosophy. Unlike the sentimental novel, which sought to educate its audience through characters that exhibited virtue, the Gothic novel aimed to portray human nature as corrupt. Within these texts readers could delve deep into the minds of deranged characters or witness acts of debauchery. Pious narrators were replaced by villain-hero protagonists who served to further blur the line between good and evil. In privileging obscurity (both in its content and form), Gothic fiction successfully challenged the Enlightenment's strong belief in rationality.

Perhaps one of the most compelling aspects of the Gothic novel is its preoccupation with the imagination. It managed to move beyond the limitations of previous literary traditions by involving the reader in an unprecedented manner. According to literary critic Robert Hume, sentimental novels invited readers to admire fine feelings while the Gothic novel sought to shock and alarm the reader (Hume 284). Authors of this genre developed stock devices such as ghosts and disembodied voices in order to provoke an extreme emotional response from their readers. The underlying purpose of many of these novels was to inspire terror. In fact, the Gothic's unmistakable interest in terror can be traced back to the philosophical inquiries of the late $18^{\text {th }}$ century. Philosophers such as Edmund Burke greatly influenced the Gothic's approach to the reader's involvement with the text. He argued that the ruling principle of the sublime was 
terror. By doing so, he emphasized the importance of violent emotions which had been deemed invaluable by the neoclassical movement (Burke 30). According to Burke, an individual could experience sublimity only through some degree of horror. It was believed that terror had both a psychological and physiological effect on the individual. In terms of psychology, terror was believed to arouse and magnify one's passions. Terror was also thought to tighten the fibers in the body thereby inducing a state of sublimity (Burke 36). Rather than to promote beauty or pleasure, nineteenth- century thought praised raw and uncensored emotions. As a byproduct of this era, the Gothic novel valued the concept of terror. Writers held their readers in suspense in hopes of affecting their imaginative faculties. The intent of Gothic fiction was to buildup the reader's anticipation so that they may be shocked or disturbed. As a result, a strong emotional response from the reader became a prominent feature of this genre.

Further contributions were made to this literary tradition when Gothic fiction writers began to experiment with themes of violence and horror. By the turn of the century, authors had begun to take an interest in the human psyche. While the earlier Gothic novel focused on the setting and atmosphere, the latter works explored the psychological development of its characters (Hume 284).An increased attention was paid to the thought process and the internalization of emotions. This shift manifested itself in various literary techniques such as the use of extensive monologues or dream sequences. By focusing on the internal rather than on the external, authors were able to pursue enduring questions. As a result, Gothic fiction became a didactic conversation in which topics of faith and morality could be openly discussed. 
Two novels that exemplify the Gothic tradition are that of Charles Brockden Brown's Wieland or the Transformation: an American Tale (1799) and James Hogg's The Private Memoirs and Confessions of a Justified Sinner (1824). Not only do these texts defy the social hierarchy of reason and order but they also depict the dangers of an overly enthused imagination. Published at the turn of the century, Brown's narrative explores the tension between the imagination and divine revelation. Unable to distinguish one from the other, the main characters enter a state of panic. Sensory perception and empirical evidence become worthless terms as disembodied voices invade the Wieland household. Similarly, Hogg's text takes a close look at the complex nature of religious enthusiasm. Confessions of a Justified Sinner exposes the problems that arise when an individual attempts to prove the existence of a supernatural entity. Wrinhim, a self proclaimed sinner, recounts his downfall into madness. Convinced by Gil that he is one of God's elect, Wrinhim commits murders and sins without any remorse. As his relationship with Gil develops, Wrinhim's perception of right and wrong are further skewed. As a result, he is rendered incapable of differentiating his imagination from reality. Much like Brown, Hogg questions the underlying difference between spirituality and delusional behavior. Both Wieland and Confessions mirror the Gothic's interest in psychology.

Divided into three sections, this thesis analyzes of the ways in which Brown and Hogg complicate the notions of spiritual enlightenment and supernatural occurrences. The first chapter titled, "Perplexing Perceptions in the Gothic Tradition" tracks the development of the Gothic novel as a genre. In providing a brief timeline of these works I propose that the Gothic novel is a complex and varied type of writing that extends well 
past the demarcation of 1820 . The latter section explores the conventions of this genre and how Brown and Hogg utilize these common "gothic trappings" in order to stress the unreliability of human rationale. This section also analyzes how fragmented narratives impede the reader from gathering whole and dependable information. As a result of the irrecoverable nature of space and time, the narrator is oftentimes unable to provide a logical explanation for the events that he/she experienced. This section will explore how space and time have a decaying effect on the narrator's memory and ability to recall past incidents. The final portion in this chapter reviews the importance of point of view. Both Brown and Hogg distort their narrator's point of view so as to demonstrate the defectiveness of testimony. Since little scholarship has been dedicated to the physicality of point of view, this section aims to redefine the Gothic perception as being driven by internal motivations yet restrained by physical locale.

"The Art of Rhetoric" explores the significant role that language plays in the Gothic tradition. This chapter examines how the antagonists in both novels are able to seduce their counterparts into action through their use of persuasive language and argumentative skills. The relationship between speaker and listener is deconstructed to provide the reader with a better understanding of the ways in which oration is depicted as a powerful talent that has the potential to control. The character's willingness to submit to a higher force makes them eligible targets of seduction. The second portion of this chapter scrutinizes the relationship between the author and the reader. Both Brown and Hogg utilize their authority as authors to manipulate the reader's response to the text. In this sub-section, the dynamics between reader and writer are likened to that of a listener and speaker. The last component of this chapter focuses on the effect that testimonies and 
confessions have on the narrators. It reveals how testimony and outside knowledge compromise both the narrator's authority and the coherency of the text.

In order to unearth the ideologies that each text challenges, the last chapter titled "Heightened Senses," offers an extensive historical overview of $18^{\text {th }}$ and $19^{\text {th }}$ century Anglo-American theology. The first section discusses how Charles Brockden Brown and James Hogg respond to the transatlantic notion of spirituality. For instance, Wieland's inclinations can be traced back to the controversial Calvinist movement which occurred during the mid 1700's in the American colonies, typically known as the Great Awakening. Wieland subscribes to this faith's popular notion which claims that only the individual undergoing a New Birth can be certain of his salvation. In a similar manner, Robert Wrinhim's religious affections can be attributed to the notoriously radical teachings of Johannes Agricola, a disciple of Luther during the Protestant Reformation. The last section highlights the complications that arise when trying to distinguish supernatural occurrences from misinterpreted experiences. The focus of this chapter is to attribute characters experiences to the larger notion of religious enthusiasm and heightened senses.

The main purpose of this thesis is to examine how the cultural tensions of $19^{\text {th }}$ century Anglo-America materialized in literature. Works written by authors such as Charles Brockden Brown and James Hogg serve as a point of reference in this complex topic. While I acknowledge that these texts offer only a limited understanding of the debates from this era, I recommend that the Gothic novel be treated as a representation of a movement toward change. It is precisely the Gothic's ability to personify political, scientific, and religious turmoil that defines its worth. By analyzing works like Wieland 
and Confessions we not only gain insight to a change in the literary tradition but also to the evolving nature of ideas within their respective time periods. 


\section{PERPLEXING PERCEPTIONS IN THE GOTHIC TRADITION}

\section{The Rise of the Gothic}

During the late 1700's, a new literary genre emerged which encompassed both elements of romance and horror. Gothic fiction became widely recognized for its unconventional prose and unprecedented display of human emotions. Unlike previous literary traditions which venerated neoclassical notions of reason and order, the Gothic novel sought to redirect its attention to Romantic ideals of extreme emotion. Much like the English Romantic poets such as Keats and Shelly, Gothic fiction writers stressed the importance of creating works that provoked astonishment in their readers. This eclectic genre challenged social constructs by privileging the unknown. Rather than being concerned with the plausibility of their narratives, authors focused on producing works that were unsettling both stylistically and thematically. In doing so, authors invited their audiences to question the relationship between the imagination and reality.

Traditionally, the limits of demarcation for the Gothic novel have been defined by the publication of Walpole's The Castle of Ontranto (1764) and Maturin's Melmoth the Wanderer (1820). Referred to as the pioneer of this genre, Horace Walpole challenged his contemporaries by authoring works of fiction that greatly deviated from customary literary conventions. His acknowledgement of the supernatural along with his unorthodox style reflects some of the defining components of the Gothic novel. Contrary to popular eighteenth-century literary figures such as Richardson and Fielding, Walpole strayed from the mundane of sentimental novels and histories. He introduced audiences to a world that was dark, dangerous, and morally ambiguous. In labeling his novel a Gothic Romance, Walpole borrowed from ancient and modern practices by combining elements 
of tragedy, horror, and romance. The Castle of Ontranto successfully distinguished itself from the masses by providing audiences with an escape from reality. A close look at Walpole's personal letters reveal that he dabbled in a new genre in an attempt to distance himself from the political and social turmoil that was unraveling during this time period (Watt 34). In making the shift from producing literature that was focused on the hardships of the everyday life to novels that explored the occult, Walpole paved the way for a new literary genre.

Most of the works that followed The Castle of Ontranto adopted a similar purpose, to awaken the reader's imaginative faculties. Authors such as Clara Reeve and Ann Radcliffe continued this literary tradition by combining elements of medieval romance and 18th century realism. Like Walpole, Reeve experimented with supernatural occurrences in realistic settings. Reeve's preface to her novel The Old English Baron (1778) reveals her decision to borrow from Walpole's plot and form. She confesses, "This Story is the literary offspring of the Castle of Otranto, written upon the same plan, with a design to unite the most attractive and interesting circumstances of the ancient Romance and the modern Novel" (Reeve 3). In paying homage to Walpole, Reeve solidifies the Gothic's worth as an emergent genre. Not only does she recognize Walpole's contribution to the canon but she also places him at the head of its genealogy. In doing so, Reeve acknowledges that there are distinct features which belong exclusively to this genre. Her efforts to distinguish the Gothic from previous forms of literature enabled authors that followed to uphold the conventions and trappings of this genre.

By the turn of the century, Gothic fiction had become a staple of Anglo-American culture. Authors continued to produce texts that transported readers into a realm of moral 
ambiguity. The Gothic novel became an avenue through which writers could address enduring questions of faith and the supernatural. One of the leading reasons as to why this genre gained such popularity was that it delved deep into the minds of deranged characters. Writers such as Matthew Gregory Lewis introduced elements of horror in hopes of provoking an extreme reaction from his readers. His highly acclaimed novel, The Monk (1796), recounts the demise of Ambrosio, a once devout priest. After falling victim to female seduction and black magic, Ambrosio veers indefinitely from the path of piety. Unlike Walpole, Lewis placed a heavy emphasis on the depravity of his characters. His elaborate description of Antonia's rape and murder were intended to both shock and repulse contemporary readers. Rather than to keep his audience in suspense, Lewis bombarded their senses through the use of explicit details and grotesque scenarios. In fact, by the mid $19^{\text {th }}$ century, a majority of the Gothic novels shared an interest in violence. Themes of debauchery and diabolism were common to the latter works. Authors like Maturin and Hogg explored the violent nature of humanity by developing villain-hero protagonists that complicated the notion of good and evil. In other words, the exploration of the human psyche became a prevalent characteristic of the Gothic novel. However, many scholars warn readers against the dangers of labeling novels that were published from 1764-1820 as Gothic. Authors such as Robert Hume explain that the Gothic novel should be viewed as more than just a compilation of aesthetics and stock devices. In his article titled, "Gothic versus Romantic: A Reevaluation of the Gothic Novel" Hume argues, "It is usually assumed that all Gothic novels are much the same, and that the form is defined by the presence of some stock devices. These "Gothic trappings" include haunted castles, supernatural occurrences, secret panels and stairways, 
time-yellowed manuscripts, and poorly lighted midnight scenes" (Hume 282). As a result of these predictable variations, many critics have approached the Gothic as a sub-literary genre. Failure to recognize a clear break from previous literary genres such as the sentimental or this historical novel has led scholars to further compartmentalize Gothic fiction. Hume suggests that in order to understand the Gothic as a genre of its own we must, "First, trace the evolution of the form, trying to see what produces its unity of impression. Second, we must attempt simultaneously to recognize the serious features of Gothic writing, distinguishing between trappings which gave eighteenth-century form its name and the essentials which the early examples share with novels in entirely different periods" (Hume 283).

Yet, the distinction that is made between stock devices and the essence of the Gothic novel is rather problematic. In drawing this comparison, Hume proposes that there is an identifiable difference between trappings and Gothic literary conventions. He argues that not all novels which exhibit Gothic characteristics (such as a convoluted plot line or mysterious occurrences) belong to this unique genre. Instead, Hume maintains that the essence of the original Gothic novel lies in its relation to Romantic literature. He likens the Gothic's exploration of the unknown and the supernatural to the emphasis that the Romantic poets placed on sublimity. Given the influence of one over the other, it is clear that Hume filters novels that were published prior to 1764 as well as those that were written after 1820. As a result, authors outside of these boundaries are excluded from being able to experience a genuine relationship to Romanticism. Thus, for Hume the Gothic novel is not only a style of writing but it is also emblematic of a historical time period. 
Although Gothic fiction may be considered a genre within Romanticism (as a type of literary expression or as an era), it stretches back earlier in its narrative providence and continues forward, in endlessly morphing high art and low art forms. Its experimental style and multifarious form has made it notoriously difficult to precisely label. While Hume attributes the "essence" of the Gothic novel to its proximity to romantic ideology, recent literary historians have steered away from this approach suggesting that such labels serve only to restrain the study of Gothicism. Questioning the validity and purpose of this timeline has led literary critics to develop more complex and fluid categories for this genre. As a result, the Gothic novel is no longer viewed as a static literary tradition; rather it is treated as a narrative technique that expresses extreme change both in the public and private spheres. This shift in perspective is perhaps most evident in the titles of recent books such as that of Robert Miles' Gothic Writing 1750-1820(1993) and E.J Clery's The Rise of the Supernatural Fiction 1762-1800 (1995). Both of these titles reflect hesitancy on part of the authors to attribute the Gothic novel to any one particular time period. Their refusal to define the Gothic novel solely by its historical context suggests that there is value to be found in this genre's flexible and discursive nature. In doing so, new criticism proposes that the Gothic novel be studied as, "a series of contemporaneously understood forms, devices, codes, figurations, for the expression of fragmented subjects" (Miles 5). Adopting this viewpoint allows us to embrace Gothicism for its aesthetic value instead of fixating on its origin. In doing so, we become less concerned with its genealogy and more interested in the Gothic novel as a hybrid genre. Other scholars such as Clery take on a similar standpoint, encouraging leniency when analyzing the roots of these novels. In fact, Clery proposes that the Gothic novel cannot 
be traced to a single origin simply because it was influenced by multiple transatlantic cultures (Clery 18). Clery's willingness to attribute the Gothic's form and style beyond the influences of Romantic literature is both liberating and encouraging. Although these critics advocate for leniency when analyzing the origins of the Gothic novel, they still view Gothicism as a literary genre that greatly differed from other literature of its time

In pushing the boundaries (of time and genre), we are able to expand our horizons and study other works that would perhaps have been excluded from this canon. Works written by authors such as Charles Brockden Brown and James Hogg were once marginalized for their unusual and intermixed style. Unlike the Gothic romance novelists that explored realistic features of everyday life, Brown and Hogg explored the minds of morally ambiguous characters. Recent scholarship has seen a growing interest in these novelists making them the focus of the study of this genre. Regarded as one of the most prolific American authors of the late 1700s, Charles Brockden Brown captivated audiences with his eerie yet complex works of fiction. His unique amalgamation of historical and fictional elements enabled him to educate his readers on cultural debates of his period while simultaneously entertaining them. Oftentimes, Brown placed ordinary characters (such as Clara from Wieland) into familiar historical periods (like the brink of the French and Indian War) in hopes of provoking anxiety within his readers. Although the settings of Brown's novels are typical and realistic, many of his themes are dark and disturbing. Novels such as Wieland; or the Transformation: An American Tale (1798) explores the minds of deranged characters and supernatural occurrences.

Exhibiting prominent features of Gothic fiction, Wieland tells the story of a kind and level-headed man that brutally slays his family after allegedly hearing God's voice. 
Narrated by Clara, Wieland's sister, this novel recounts the events that led up to the destruction of the once peaceful and pastoral family. Said to have inherited his father's religious enthusiasm, Wieland spends the majority of his time studying religious and philosophical tracts. Meanwhile, his family (Clara, Catherine, and Pleyel) enjoy a carefree and almost idyllic lifestyle involving poetry readings and reenactments of plays. However, their harmony is disrupted once a disembodied voice intrudes on the Wieland compound. Unable to find a source (physical entity) for the voice, the Wieland family becomes intrigued by this seemingly supernatural occurrence. At first, the voice simply warns them of looming danger and foretells the future. Yet, as time progresses the voice begins to threaten characters such as Wieland and Clara.

As the voice becomes a reoccurring incident, the Wieland family begins to doubt their sanity and their senses. Shortly after the manifestation of the voice, Pleyel (Wieland's brother- in-law) introduces the family to his mysterious friend named Carwin. Unsuspecting, the Wieland family welcomes Carwin into their home and invite him to stay. Frustrated and scared for their safety, they confide in Carwin and ask for his unbiased opinion. Carwin carefully listens to all of their testimonies and reassures them that there must be a logical explanation to the voice. At first, Carwin's stoic demeanor fails to alarm the Wieland family. However as the story progresses, we learn that Carwin is responsible for the voices. As a talented ventriloquist, Carwin is able to project his voice as well as impersonate that of others. Ultimately, it is Carwin's sensory-bending art form that convinces Wieland that he has been mandated by God to sacrifice his family. Although Carwin never admits to impersonating God's voice, he does take responsibility for all of the other incidents. As a result, it is unclear as to whether Wieland's actions 
were a result of Carwin's ventriloquism or if they were a byproduct of Wieland's religious enthusiasm.

Like many other Gothic novels, Wieland concludes in an abrupt and unfinished manner. Hoping to flee the madness that once surrounded her, Clara resolves to move to Europe. Unable to provide logical or even a factual account, Clara struggles to provide her reader with closure. The last few pages of the novel are Clara's attempt to moralize the horrific occurrences. Realizing that she may be perceived as an incredulous narrator, she decides to conclude the novel with a seduction story. In the end the story blames the victims for their lack of good judgment, leaving the perpetrators unmentioned and free of culpability.

Much like Brown, Scottish author James Hogg, wrote novels that pushed the boundaries of realism. Although Hogg received little formal education, he experienced a fruitful career as an author from 1801 until the mid 1830's. He composed a variety of works ranging from poems, plays, novels, and songs. Mainly concerned with the experiences and insights of the rural people, Hogg published books that immerse the reader in the Scottish culture and tradition. Similar to Brown's literary techniques, Hogg manipulates dates and locations so that individuals are displaced in ambiguous settings. Maintaining this level of familiarity yet foreignness enables Hogg to play with our perceptions of truth. Reality is oftentimes interjected into fictional locales or situations so that the reader must struggle to differentiate fact from fiction.

Today, James Hogg is best known for his Gothic novel titled The Private Memoirs and Confessions of a Justified Sinner (1824). Its obscure and convoluted characteristics have prompted many scholars to label this novel as one of the most 
important contributions to the genre of Gothic fiction. Divided into three parts, the first section is a factual account according to Scottish folklore. Set in the 18th century, the novel introduces the reader to the tumultuous marriage of Rabina Orden and George Colwan. Innocent and pious Rabina spends her time avoiding her unholy and violent husband, the Laird of Dalcastle. Her religious rigor aggravates her husband and is the cause of many of their fights. Unable to live in each other's presence, the couple decides to separate. Throughout the course of the novel, Rabina becomes pregnant with her first son George who is immediately sent to live with his father. During their separation, Rabina gives birth to a second son, Robert Wrinhim, who is rumored to be the love child of Rabina's spiritual advisor Wrinhim.

Because of the speculations of infidelity, the first son is announced sole heir of the throne while Robert Wrinhim and his mother are proclaimed outcasts. Raised separately, George is described as a centered, well meaning, and kind young man. On the other hand, Wrinhim inherits both his mother's religious vigor as well as his Reverend's father lust for power. Wrinhim is described as a malicious and selfish individual who is driven by greed. Raised in a radically Calvinistic family, Wrinhim is indoctrinated into the society of the just. His confirmation of God's election enables him to commit sins without fear of losing his privileged state. Wrinhim's religious beliefs showcase Hogg's interest in the ambiguity of religious interpretation. In depicting Wrinhim as a man who uses religion to excuse his sins, Hogg highlights the underlying hypocrisy of blind faith.

As the narrative progresses, Wrinhim's immoral behavior only worsens. He begins to stalk his brother George and threatens to kill him. As the first section draws to a close, Wrinhim is accused of murdering his brother with the help of another culprit. Once 
the heinous crime is made public, the law sets out on a desperate search only to find no traces of him.

The inconclusiveness of the first section allows the second portion of the narrative to fill in the reader's gaps of knowledge. Narrated by Robert Wrinhim, the second part of the narrative is a collection of his confessions. This section is perhaps most emblematic of the Gothic tradition, seeing that it is narrated by a crazed criminal. The scattered account leads the reader to believe that Wrinhim is seduced into sinning by a supernatural character named Gil Martin. Gil is described as a shape-shifting doppelganger that has the ability to control Wrinhim's free will. Initially, their relationship stems from a shared curiosity in one another. However, by the end of the confessions Wrinhim curses his naivety and inability to escape Gil. Wrinhim admits to being lured into a life of sin yet he denies having acted alone. Given the changes of point of view from the first portion of the novel to the second, the reader must choose who to blame for the murders. Either Wrinhim is truly delusional and Gil is just a figment of his imagination or Gil truly exists and has driven Wrinhim to a state of depravity. Whatever the case, Hogg (like Brown) allows the reader to arrive at their own conclusion.

The last part of the narrative is told from the perspective of James Hogg. Both the narrator and author of this book, Hogg includes himself as a character towards the final scenes. A group of writers excavate the body of Wrinhim only to find that he was buried with his confessions. The finding of the text is both exhilarating and confusing, leaving the reader struggling between two realities.

Comparable to Wiealnd, Confessions of a Justified Sinner explores the dangers of unchecked religious experiences and the imagination. In fact, both authors utilize similar 
narrative techniques to comment on the unreliability of the human mind. The following section will analyze the ways in which Brown and Hogg use Gothic literary conventions to further complicate the relationship between truth and fiction.

\section{Gothic Conventions}

A great majority of literary critics maintain that the value of Gothic fiction rests in its power to challenge realism. In her book titled The Coherence of Gothic Conventions, Eve Kosofsky Sedgwick explains that although highly formulaic, Gothic conventions serve as indicators of texts that are willing to articulate intense exploration of the human psyche. The point of the Gothic is to, "enlarge the sense of reality and its impact on the human being" (Sedgwick 3). Indeed, the lines between truth and fiction are blurred in Gothic fiction to the extreme where it is becomes difficult (if not impossible) to discern the imagination from reality. The question then becomes, how does this genre represent the supernatural as a viable and tangible entity? How do authors of Gothic fiction depict empirical evidence as weak and oftentimes lacking? Furthermore, how are failed senses differentiated from heightened senses? Queries such as these suggest that Gothic fiction uniquely encodes the very question of knowing itself in its conventions, most particularly in the rendering of point of view. Authors of these novels choose to incorporate literary conventions such as the use of multiple narrators to obscure the perception of truth. In fact, the Gothic novel tends to deprive the reader from the comfort of a reliable narrator. Contradictory testimonies and faulty experiences taint the character's ability to produce a coherent account. On several occasions, multiple narrators interject throughout the course of the novel without offering any new or dependable information. Given the subjectivity 
of point of view, it becomes evident that narrators of Gothic fiction complicate the palpability of truth.

Not only does the Gothic novel obscure the concept of truth through its character development but it also strips rationalism from its explanatory power. In other words, the scientific approach to a single truth does not hold within these narratives. The narrators are unable to deduce veracity from their experiences. Truth becomes a subjective term that is shaped by a character's internal motivation and point of view. Motive and perspective are used to further magnify the uncertainty of a character's account. For instance, Carwin's motives remain secret up until the final pages of the narrative. In a similar fashion, the driving force behind Wrinhim's actions remains a mystery even at the end of his confessions. It is precisely this looming sense of the unknown that the Gothic novel seeks to explore.

It is perhaps of equal importance that we understand the purpose of these literary conventions. It is necessary to both identify commonly used narrative techniques within this genre and to recognize their intended effect. For instance, what are the ways in which Gothic novelists manipulate the release of information? Or, how does an unreliable narrator impact a reader's ability to ascertain truth within a narrative? This section aims to explore the possibilities to these questions by taking a close look at the novels written by Charles Brockden Brown and James Hogg. In his novel, Wieland or the Transformation: An American Tale (1798), Brown explores the ways in which point of view affects a narrator's ability to be considered a credible source for information. Like most authors of Gothic fiction, Brown distorts the form of the narrative through the use of 
multiple narrators and fragmented episodes. Sedgwick refers to this type of Gothic convention in the following manner,

Of all the Gothic conventions dealing with the sudden, mysterious, seemingly arbitrary, but massive inaccessibility of those things that should normally be accessible, the difficulty of the story has in getting itself told is of the most obvious structural significance. The difficulty occurs at every level of the novels (Sedgwick 14).

Sedgwick's obvious frustration with the Gothic is very much applicable to Wieland, where the characters fail to provide logical or even coherent accounts of their experiences. The inability to produce an empirically sound or rational story is one of the most well-known, and perhaps most criticized, aspects of Gothic fiction. Although this literary convention may have an aggravating effect on the reader, its purpose is unmistakably clear. By incorporating multiple unreliable narrators the "truth" or "reality" of an episode becomes disputable. Brown challenges the validity of a single truth by having Wieland interject during the last portion of the narrative. By taking over the text, Wieland hopes to provide Clara with clarity as to why he chose to murder his family.

However, rather than to bring forth a logical explanation for his actions Wieland's confession helps to only further complicate the unraveling of events. His admission is detached and vacant of emotion, claiming that his actions were a response to God's will. By deflecting responsibility to a higher being, it is neither Clara nor Wieland that can attest the truth of these events. Clara was not present at the time of the murders and there is reason to believe that Wieland may be suffering from hallucinations. The question then remains, how can truth be extracted from a story that has multiple narrators? One must 
keep in mind that the Gothic novel intends to test our abilities to deduct "truth" from reality by presenting the reader with unsettling episodes. Both Clara's and the reader's inability to come to a solid and provable conclusion suggest that truth is subject to the interpreter's point of view. In the midst of all the chaos, Clara attempts to rationalize the massacre however she quickly finds herself powerless to make any assertions. She writes, "Presently I considered that whether Wieland was a maniac, a faithful servant of his God, the victim of hellish illusions, or the dupe of human imposture, was by no means certain" (Brown 214). Like Clara, we are faced with the incertitude of reality. Coherency and logic are optional in Gothic fiction. As a result, the reader and the characters must relinquish their search for a single truth.

Similarly, James Hogg complicates the concept of truth by revealing partial insight through the use of tattered manuscripts. In his novel The Private Memoirs and Confessions of a Justified Sinner (1824), Hogg teases his audience with the possibility of arriving at a "wholesome" or single truth by introducing a mysterious manuscript. Although heavily soiled and hardly legible, the reader hopes to gain access to privileged information. The anticipation of unearthing such a crucial piece of information builds up the reader's tension as he/she anticipates to be cleared of all confusion. However, like most other Gothic conventions, the manuscript fails to provide the reader with any new insight. As Sedgwick explains in her book, the purpose of the manuscript is to construct, "a-story-within-a-story-within-a-story". The theme of crumbling manuscripts becomes an essential part to the form of the Gothic novel. Therefore, the unveiling of seemingly crucial and revealing information only serves to further isolate the reader from the truth. The use of the manuscript also functions as a reminder that time deteriorates and distorts 
the truth. The more time that passes by within the narrative, the lesser the chances are that the reader or the narrator will arrive at a logical explanation. The distance that is created between the past and present is also represented in terms of space.

Sedgwick explains that when dealing with Gothic fiction, space is not only limited to actual physical boundaries. Space can be that which is created by memory loss or an irretrievable history. In relation to Hogg's novel, the manuscript becomes symptomatic of the narrator's inability to piece back together the past. The final narrator of The Confessions of a Justified Sinner arrives at this conclusion when he excavates the remainders of Wrinhim's manuscript. After laboring for hours over the grave site, the narrator comes across what seems to be a journal of some sort.

We were all so curious to see what kind of pamphlet such a person would read; what it could contain that he seemed to have such a care about. But the pamphlet was so damp, rotten, and yellow that it seemed one solid piece. We all concluded from some words that we could make out that it was a religious tract, but that it would be impossible to make anything of it (Hogg 227).

The initial enthusiasm of finding an antique manuscript is quickly subdued by the scavengers' realization that the manuscript is in less than desirable conditions. The narrator's inability to gather a complete account of Wrinhim's confessions suggests that only fragmented truths can transgress time and space.

The issue concerning the palpability of truth does not simply rest in the differing points of view that lead to contradictory truths. In other words, the characters in these stories are seduced by inadequate and impartial sources of knowledge which are presented to them in the forms of books, letters, and voices. However, it is inevitable to 
notice that these sources are archaic and misleading. For instance, Wieland chooses to follow the commands from a voice that lacks a physical entity. While he assumes that the voice is supernatural (and therefore not really there) he still allows himself to be seduced by the concept of the unknown. Logical explanations that could be easily provided by science are not enough to deter Wieland from falling victim to the disembodied voice. Similarly, Wrinhim obeys the commands of Gil without questioning his authority or his self proclaimed status as God's warrior. Although Wrinhim suspects that Gil has an ulterior motive for keeping his company, he still chooses to follow his lead. Both Wieland and Wrinhim are aware that Gil and Carwin represent misleading information yet they choose to accept them as objects of truth. The question then becomes, why are the characters of these novels seduced by these perplexing perceptions? If knowledge is derived from physical proof which then leads to a rational explanation, then why do Wieland and Wrinhim privilege the un-truths? I propose that the Gothic novel aims to complicate our reliability on facts by demonstrating the ease with which our senses (and opinions) can be swayed. Although Wieland appears to be a man of science, the possibility of the existence of the unknown proves to be too tantalizing to reject. As a genre, Gothic fiction brings these inconsistencies to light in order to illustrate the fickleness of human reasoning.

In addition to the misinterpretations of truth, Gothic fiction writers such as Brown and Hogg manipulate the reader's knowledge of the narrative through the use of character memory loss. A closer look reveals that this literary convention is an essential part of both the form and content of the Gothic novel. In presenting readers with characters who are unable to confide in his/her own experiences the author raises the question whether it 
is possible to have an intact narrative. The theme of discontinuity emphasizes the problems that arise when trying to recount one's experiences with the external world. Just as the characters in the story are unable to provide logical explanations for their experiences, the reader is rendered incapable of finding cohesion within the narrative. Therefore, the relationship between the narrator and the reader become codependent. The narrator's memory loss or distortion of events results in the reader's fragmented interpretation. According to Sedgwick, characters in Gothic fiction are oftentimes faced with situations in which they are unable or unwilling to bear witness. In this case, the desire to know the truth remains unfulfilled because of the narrator's refusal to fully participate in the unraveling of events. Sedgwick explains duality as follows, the self and whatever it is that is outside have a proper, natural, necessary connection to each other, but one that the self is suddenly incapable of making. The inside life and outside life have to continue separately, becoming counterparts rather than partners, the relationship between them one of parallels and correspondences rather than communication (Sedgwick 13).

Like Sedgwick, I propose that the narrators of these novels are faced with situations that threaten the safety and reliability of their realities. By mentally disconnecting themselves from traumatic or uncomfortable experiences, the characters in these stories are able to cope with a selective reality. As a result, the narrators in these stories construct a biased and unrealistic account of their experiences due to their unexpected memory loss.

In Wieland, Clara occasionally suffers from fainting spells when faced with a dangerous or life-threatening situation. The terror of the unknown causes Clara to 
disconnect her mind from her physical state. In doing so, Clara creates a self-defense mechanism which allows her to evade the responsibility of having to bear witness. One of the most pivotal moments in this story is affected by Clara's memory loss. During a particular episode, Clara finds herself unable to cope with reality when she hears the voices of strange men plotting her murder. The lack of physical evidence that someone has intruded into her home causes even more anxiety, leading Clara to question the validity of her own senses. Clara's reaction to immediate danger is as follows, Flight instantly suggested itself as most legible in circumstances so perilous... I can hardly recollect the process of turning keys, and withdrawing bolts. My terrors urged me forward with almost a mechanical impulse. I stopped not till I reached my brother's door. I had not gained the threshold, when, exhausted by the violence of my emotions, and by my speed, I sunk down in a fit. How long I remained in this situation I know not (Brown 66).

Clara's memory loss further complicates the notion of a reliable narrator since she is unable to vouch for her own experiences. Clara's sparse recollection of events suggests that point of view is consciously structured by the characters of Gothic novels. As a literary convention, Clara's memory loss becomes an obstruction in the reader's search for veracity and clarity. In fact, it could be argued that Clara takes the reader away with her once she flees from her home. Like Clara, we are left wondering whether the voices were a manifestation of her imagination or if they truly were a byproduct of murderers plotting her death. It is precisely the ambiguity of scenes such as this that prompt the reader to question the validity of the narrator's point of view. 


\section{Constructing Point of View}

Spectatorship takes on a voyeuristic approach both in Wieland and Confessions of a Justified Sinner. The narrators of these stories oftentimes witness events either in partiality or from a distance, resulting in fragmented and inaccurate perceptions. It is precisely the Gothic's preoccupation with the visual that leads the characters to develop distorted points of view. As mentioned earlier, the form and style of the Gothic novel mirror the character's incomplete interpretation of events. For instance, in Wieland Clara is a witness to various strange occurrences however her ability to deduce information is limited due to her obscured vision and bewildered senses. Similarly, in Confessions the witnesses to a brutal murder are unable to provide an accurate account because of their inability to clearly see the murderer or to hear the dialogue. Both of these instances suggest that point of view is not merely constructed by a character's internal faculties (emotions and opinions) but also by the physical space which the character occupies. Little scholarship has been dedicated to the physicality of point of view. Literary scholars have focused on the emotional and psychological aspect of perception. However, there is a lack of research concerning point of view and physical space. I contend that by redefining point of view in the Gothic novel it is possible to distinguish internal motivation from physical boundaries. In order to better understand the manner in which space and physical locale affect the narrator's perception of "truth" it is necessary to analyze a few brief passages from Wieland and Confessions.

The fascination with occult places and midnight murders is clearly evident in both of these novels. However, the purpose of employing such predictable literary conventions is not as apparent. How do dark alley ways and disembodied voices influence a 
character's point of view? How do physical spaces alter a character's mental and emotional capacities? In her essay titled, The Importance of Point of View in Brockden Brown's Wieland, William Manly explains that as spectators of this novel our point of view is predominantly shaped by Clara's eyes. Since Clara is the narrator for the majority of the novel the reader must choose to either accept her as a reliable narrator or question the validity of her account. In comparison to other characters Clara seems to maintain a levelheaded approach to the strange occurrences. In fact, it could be argued that Clara's objectivity is presented as a desirable characteristic when contrasted against Wieland's religious enthusiasm or Pleyel's ultra-rational personality. "Clara displays from the beginning a far more rational and controlled intelligence than that of the typical sentimental heroine. Even random samplings of her conversation have a philosophical rigor" (Manly 312).

When disembodied voices become a recurrence in the Wieland compound, Clara decides to exhaust all possible logical explanations before doubting her own senses. In fact, her reaction to Wieland's delusions echoes Locke's theory of the self. Like Locke, Clara maintains that knowledge is derived from our everyday experiences. Her reliance on empirical proof suggests that she trusts her senses to provide her with true and palpable information. The correlation that Locke draws between perception and knowledge is crucial to the understanding of Clara's belief system. According to Locke's epistemology, our perceptions represent objects that exist in the physical realm. In other words, it is through our senses that we are able to determine whether an object is truly present. Our sensations (sight, sound, smell, touch, and taste) shape our perspectives of the objects that we interact with. Because of this, Locke argues that we are able to assert 
the existence of substances. In Clara's case, she hears the voice yet she is unable to confirm its source. While her hearing assures her that the voice exists her sight cancels out the possibility of this conclusion. This mixing of the senses puts Clara in a predicament. Lockean sensational psychology provides two possible explanations for Clara's encounters. Either Clara's senses are flawed, making her a victim of delusion, or Clara has yet to discover the source of the external voice. Upon encountering this inconsistency in her senses, Clara attempts to rationalize her experience. She blames her imagination and quickly resolves to forget the incident. Yet, Clara learns that she cannot dismiss the voice once she clearly hears it again for the second time. Clara's inability to derive knowledge from her sensory experiences subverts the Lockean model of the identity of substances. Not only does Clara's testimony of events create anxiety within herself but it also forces the reader to question the validity of her experiences.

As the narrative progresses Clara's unwavering logic and reason comes across as forced and artificial. Her desire to impress readers with her ability to remain unaffected by the chaos raises questions in regards to the validity of her point of view. Upon hearing strange voices in her apartment Clara calmly remarks,

In the first impulse of my terror, I uttered a slight scream, and shrunk to the opposite side of the bed. In a moment, however, I recovered from my trepidation. I was habitually indifferent to all the causes of fear, by which the majority are afflicted. I entertained no apprehension of either ghosts or robbers (Brown 64). At first blush, this passage might seem trivial in regards to Clara's purpose as a narrator. However a closer look reveals an unsettling aspect to Clara's calm and collected delivery. Rather than being inundated by thoughts of fear and horror, Clara quickly 
recovers from her trepidation. She sneers at the idea of believing that the voices were that of robbers or ghosts. Given the strange nature of the circumstances, one would expect Clara to panic or to react in a much more frantic manner. However, after hearing the whispers numerous times Clara announces, "No other conclusion, therefore, was left me; but that I had mistaken the sounds, and that my imagination had transformed some casual noise into the voice of a human creature" (Brown 65). Clara continues to reassure both herself and the reader that the human whispers must have a logical explanation. Her speculation spans over the course of several pages in which she blames the noises on either the maid or her imagination. In fact, Clara refuses to fathom the possibility that the voices could be a manifestation of the supernatural. She refrains from showing any signs of fear or doubt in an attempt to build her credibility as a witness to these events.

As mentioned earlier, in order to better understand how a character constructs their point of view it is necessary to study space and physical positioning. When Clara hears the whispers for the second time she is positioned within a secluded dark space. Because of her lack of visibility and connection to the remainder of the house, Clara assumes that the whispers were that of her maid Judith. However, Clara soon realizes that her physical positioning prevents her from affirming her suspicions. Clara writes, Full of this persuasion, I called; "Judith," said I, "is it you? What do you want? Is there anything the matter with you? No answer was returned. I repeated my inquiry, but equally in vain. Cloudy was the atmosphere, and curtained as my bed was nothing was visible. So I withdrew the curtain, and leaning my head on my elbow, I listened with the deepest attention to catch some new sound. Meanwhile, 
I ran over in my thoughts, every circumstance that could assist my conjectures (Brown 64).

By alluding to the "cloudy atmosphere" and her obstructed visibility Clara suggests that her physical positioning limits her ability to deduct information. Not only does the room isolate Clara from the rest of the house but it also keeps her within an arm's reach of danger. The question then becomes, could Clara's point of view possibly be skewed by the physical space which she occupies. In other words, can the reader trust Clara's observations regarding the voices considering the auditory and visual limitations that she is faced with? Clara's point of view (both literary and literally speaking) are affected by her lack of clarity and perspective. Being enclosed in her room, Clara is unable to discard the possibility that an intruder has entered her premises.

Realizing the flaws in her argument, Clara decides to comfort readers by providing an extensive and detailed description of her home. In doing so, Clara hopes to regain the trust of her readers and simultaneously prove that there is no physical way that anyone could have entered her home. Clara defends her point of view in the following manner,

The door which led into the adjoining chamber was close to my bed-head, and was always locked, but when I myself was within. The avenues below were accustomed to be closed and bolted at nights. The maid was my only companion, and she could not reach my chamber without previously passing through the opposite chamber, and the middle passage, of which, however, the doors were usually fastened (Brown 65). 
In this passage, Clara surveys the layout of her home as a final effort to validate her claim. Although Clara asserts that the apartment is "usually fastened" the reader cannot help but to wonder whether someone has intruded. The voices in Clara's apartment suggest that there is an intruder in the house however the lack of physical evidence indicates differently. The reader cannot trust Clara's point of view because it skewed on various levels. As a result of conflicting evidence, Clara's conclusion is rendered invalid.

Furthermore, as readers, we must be wary of the ways in which Clara's detached and almost reportorial tone might seduce us into perceiving her as a trustworthy and unbiased narrator. Throughout the narrative her voice is devoid of emotion as she desperately struggles to restore order by recording events in a linear and coherent manner. Clara's inability to liberate her emotions and to explore the unknown leads her to question the truth behind the sequence of events. Clearly, her efforts to provide readers with a believable narrative are paradoxical in nature. When analyzed carefully, Clara's fixation with order and truth begin to seem out of place, especially within the Gothic novel. Her common sense approach is challenged by both the form and style of this literary tradition. In terms of aesthetics, Clara attempts to turn a disorderly sequence of events into a tidy narrative. Her use of the epistolary format allows her to keep control over what would otherwise be an inconclusive story. Her pragmatic perspective serves as a commentary on the limitations of human knowledge and Enlightenment principles. Her inability to draw a believable conclusion suggests that her rational approach is outweighed by the overwhelming amount of incoherent evidence.

Hogg's Confessions of a Justified Sinner encapsulates the meaning of the Gothic literary tradition. As Magdalene Redekop notes in her article, "Beyond Closure; Buried 
Alive with Hogg's Justified Sinner" point of view is at best a blurry subject matter in this novel. The interlacing of multiple narrators provides readers with different points of views and unique interpretations as the events unravel. However, it is precisely the disparity between these accounts that prevents readers from arriving at a single shared truth. Unable to discern fact from opinion, the reader is forced to study each narrative independently and then once again as a whole in hopes of arriving at a logical conclusion. I contend that by paralleling these narratives the reader is able to sift through the partisan views and better understand the ways in which Hogg intentionally problematizes the Gothic novel.

The purpose of the first narrative is to contextualize Wrinhim's life story and to provide a seemingly unbiased historical account of the events that ensued. However, it soon becomes clear that even the folklore version is highly opinionated and onedimensional. Wrinhim is introduced to readers as a malicious character who for unknown reasons seeks revenge on his royal half-brother. The lack of character development forces the reader to view Wrinhim as a purely evil person who becomes more monster-like as the story progresses. Upon meeting his brother George for the first time, Wrinhim is described as acting like a rabid animal. After engaging in a violent dispute, Wrinhim is illustrated as behaving in the following manner "In the meantime, young Wrinhim was an object to all of the uttermost disgust. The blood flowing from his mouth and nose he took no pains to stem, neither did he so much as wipe it away; so that is spread over all his cheeks, and breast, even off at his toes" (Hogg 23). Unfamiliar to Wrinhim's motives, the reader assumes that this is a volatile and demented individual. Shocked and confused by Wrinhim's gruesome behavior, one is left to speculate what provoked such a violent 
reaction? Why was Wrinhim so quick to despise and later on destroy his brother? These are all questions that remain partially unclear if not unanswered until the second section of the narrative in which Wrinhim attempts to logically explain the purpose of his actions. In fact, most of the first portion of the narrative is designed to alienate the reader from Wrinhim. As a result, the reader comes to view Wrinhim as a deranged murderer. Had this narrative been strictly limited to the folklore version, the reader would not be able to understand the reasoning behind Wrinhim's behavior. However, as the story shifts narrators the reader gains insight into the character's private thoughts. As a result, not only does the change in narrator provide readers with a different perspective of the story as a whole but it also allows for a better understanding of Wrinhim's twisted belief system.

Perhaps one of the most perplexing characteristics of the first narrative is that Wrinhim is presented as a supernatural entity. Witnesses see him in more than one place at the same time and attribute to him shape-shifting abilities. One of the most interesting accounts is that of Miss Calvert who witnesses the murder of George. In this particular scene, the spectator's viewpoint is posed as highly problematic because of the character's lack of moral integrity and her physical location. Miss Calvert is introduced as the only witness who is willing to divulge the events that led up to the murder of George. However, the reader is hesitant to fully accept her as a credible source because of her past occupations as a con artist and prostitute. Miss Calvert's reasons for coming forward are not made clear thereby further fueling the reader's doubts. Although viewed as an unreliable narrator, Miss Calvert's account is still deemed valuable in the sense that it 
provides a rough outline of the events that unraveled on the night of George's murder. Her interpretation is as follows:

When I looked down at the two strangers, one of the he was extremely like Drummond. So like was he that there was not one item in dress, form, feature, nor voice which I could distinguish one from the other. I was certain it was not he, because I had seen the one going and the other approaching at the same time, and my impression at the moments was that I looked upon some spirit, or demon, in his likeness. I felt a chillingness creep all around my heart, my knees tottered, and, withdrawing my head from the open casement that lay in the dark shade, I said to the man who was with me, 'Good God, what is this?'... When I peeped over again, the two men were disputing in a whisper, the one of them in violent agitation and terror, and the other upbraiding him, and urging him on to some desperate act (Hogg 68-69).

Within these lines, Miss Calvert alludes to the possibility that the murderer has supernatural capabilities. She describes him as one that can take on another man's identity in a seamless manner. The strange man takes on the appearance of George's friend and aids Wrinhim in his plot of revenge. Much like Clara, her sight is obscured by the dark of the night and her hearing is affected by the distance between herself and the murder scene. She is described as peeking through her bedroom window and struggling to hear the dialogue that is exchanged between the two strange men. She notices a third man hiding behind the shadows who eventually drags George into the shadows and slays him. Even though Calvert's point of view is obstructed the reader finds a compelling aspect to her narrative. Her version provides readers with confirmation that Wrinhim was 
indeed responsible for the death of his brother. By attesting to the reader's suspicions, Miss Calvert's testimony serves as a lead in the quest for a viable explanation.

In his private memoirs, Robert Wrinhim confesses to murdering his brother and further supports Miss Calvert's account. However, Wrinhim does not depict himself as completely culpable for the violent affair. In fact, to the reader's surprise Wrinhim accuses Gil Martin (a mysterious shape shifting character) for his sins and murders. As a result, Wrinhim's perspective of the ominous night differs greatly from Calvert's point of view. According to Wrinhim, Gil Martin seduced him into believing that his status as God's elect required him to slay those who were unworthy of salvation. Gil's powerful words and convincing rhetoric incite Wrinhim to take part in malicious acts. Wrinhim's interpretation of the fateful night is the following,

My royal friend and my brother fought round the green to the very edge of the water, so round till they came close up to the covert where I stood... I could resist no longer; so, springing from my concealment, I rushed between them with my sword drawn, and parted them as f they had been two school boys. The ungodly and reprobate young man fell covered with wounds and with curses and blasphemy in his mouth, while I escaped uninjured (Hogg 155).

Wrinhim's recollection of the murder is comparable to that of Calvert. However his rendering deviates from her version in the sense that he exculpates himself from any wrongdoing. As the narrative progresses, Wrinhim shifts the focus onto Gil's cunning ways and his deceptive plan. He regrets straying from the teachings of his father and curses Gil for transforming him into a justified sinner. However, because of the strange and imaginary like characteristics of Gil Martin the reader is unable to discern whether he 
is an actual supernatural force or if he is merely a figment of Wrinhim's imagination. Upon the completion of Wrinhim's confessions the reader is left with two options: either Wrinhim is a delusional character who refuses to accept responsibility for his own actions or Gil Martin is an existing force that drives Wrinhim into a state of insanity. Both of these options suggest that Wrinhim's narrative suffers from a lack of coherency and sustainable information. The text leaves undecided whether Wrinhim is accountable for the wrongdoings or if the horrifying sins are a byproduct of Gil's actions. In blaming Gil Martin, the reader concedes to Wrinhim's point of view by ultimately accepting the existence of a supernatural entity. On the contrary, by rejecting Wrinhim's narrative the reader is faced with an inconclusive conclusion.

When analyzing the final section of the book, the reader realizes that truth is not easily found within these narratives. Magdalena Redekop places great emphasis on the chilling conclusion claiming, "Nowhere is this conjunction of gothic effect with problems of interpretation more explicit than in the concluding frame of the novel where the text itself is discovered in the grave of the Scots mummy" (Redekop 160). After unearthing the remains of Wrinhim, Hogg discovers the manuscript of the confessions. This terrifying yet thrilling finding poses a new threat to the reader's understanding of the events. Redekop explains,

The reader is left in an intensely realized predicament: the text demands rereading and interpretation even as it mocks our efforts to do so. Like Poe, Hogg uses the image of being buried alive as a metaphor for intensified self-consciousness, and the result is that as readers we become vividly aware of the free mind - our own 
participating intelligence - buried in the body of the text, engaged in a constant struggle to escape through understanding (Redekop 162).

Once again, the reader is exposed to a different viewpoint, one that further challenges the validity of Wrinhim's narrative. Hogg concludes "it is certainly impossible that these scenes could ever have occurred that he describes as having himself transacted... that this wretch slew his brother, there is to me a good deal. However, allowing this to have been the case, I account all the rest either dreaming or madness; or as he says to Mr. Watson, a religious parable, on purpose illustrating something scarcely tangible, but to which he seems to have attached great weight" (Hogg 229). By publishing Wrinhim's confessions and rendering it a work of fiction, Hogg further distances the reader from the truth. In labeling the confessions a failed religious parable, the author mocks the reader's attempts to discern fact from fiction. By presenting readers with this possibility, Hogg highlights the unreliability of Gothic novel narrators.

Both Wieland and Confessions of a Justified Sinner push the reader's ability to predict the plot of a narrative or the conclusion to a story. It is precisely the anxiety that stems from the reader's inability to arrive at a logical conclusion that defines the essence of the Gothic novel. Authors of Gothic fiction paved the way for future literary genres to question the validity of reason and uphold the necessity for confusion. 


\section{THE ART OF RHETORIC}

Disembodied Voices and Doppelgangers

Emblematic of the Gothic tradition, both Wieland: or, the Transformation and Confessions of a Justified Sinner explore the minds of deranged and dangerous characters who not only threaten to disrupt the coherency of the narrative but also to thwart the ability of the protagonist to discern actuality from the imagination. Characters such as Carwin (the biloquist) and Gil (the doppelganger) challenge the narrators' conception of certainty by introducing alternate realities that further question the possibility of arriving at a single truth. Originally interpreted as a disembodied voice, Carwin's commands and cautionary messages produce chaos in the once peaceful compound of the Wieland family. Similarly, it could be argued that Gil's admirable argumentative skills and rhetorical abilities are what truly prompt Wrinhim to finally accept his role as a justified sinner. The thread of commonality between these two antagonists is their effortless ability to persuade and essentially seduce their victims into submission. The rhetorical appeals of ethos, pathos, and logos are terms that can easily be applied to Wrinhim's and Carwin's speaking skills. In regards to ethos, both antagonists manipulate their listeners by establishing a sense of credibility. For instance, Gil convinces Wrinhim that he is God's messenger thereby elevating his authority. Similarly, Carwin's voice demands respect not only because it suggests the possibility of a supernatural entity but also because it warns its listeners. Carwin and Gil are also able to manipulate their victims through their use of pathos. Both villains fasten their control over Wieland and Wrinhim by appealing to their religious enthusiasm. Like Carwin, Gil plays with Wrinhim's emotions by assuring him that God has mandated him to sin. Perhaps even more interesting are the ways in which Gil and Carwin use logos to appeal to their listener's 
rationale. Although both characters oftentimes propose illogical and immoral behavior, they manage to convince Wieland and Wrinhim to obey. By presenting logical and convincing arguments, Gil and Carwin prompt their victims to commit heinous crimes. Both Carwin and Gil utilize pathos in order to appeal to their listeners. As a result, Wieland and Wrinhim are overpowered by emotions of despair, guilt, and admiration. Their inabilities to control their emotional responses turn them into victims of rhetorical seduction. In these narratives, polished rhetorical skills enable characters to exercise autonomy and independence. Voice is depicted as a dangerous faculty that has the potential not only to persuade but to command power over others.

In these texts, rhetorical eloquence becomes a marker for authority, where the speaker's oratory skills are symptomatic of their power over the listener. Much like preachers, who utilize public speaking and sermons to convert masses of eager listeners, both Gil and Carwin employ language to manipulate their audiences. As a result of this hierarchy, Wrinhim's and Wieland's ability to reason or act independently are replaced by the unexplainable desire to obey the commands of their counterparts. Upon relinquishing their autonomy, these characters fall victim to misinterpreted authority. Since the sources for these voices are not always clear or identifiable, the characters are left searching for a cause and explanation to their actions. This chapter will analyze the relationship between speakers and listeners in these two novels and further explore the ways in which oration is depicted as a powerful talent that has the potential to control and captivate audiences.

Confessions of a Justified Sinner introduces the reader to Wrinhim, a problematic character who eagerly awaits confirmation of his status as one of God's elect. As a 
follower of the radical teachings of Johannes Agricola, a disciple of Luther during the Protestant Reformation, Wrinhim firmly believes that his sins cannot alter God's will. Confident in the doctrine of predestination, Wrinhim becomes accustomed to committing sins without fear of consequences. This skewed interpretation of moral integrity leads him to conclude, "I had more sense than to regard that either my good works, or my evil deeds, as in the smallest degree influencing the eternal decrees of God concerning me, either with regard to my acceptance or reprobation, I depended entirely on the bounty of free grace" (Hogg 104). Wrinhim's attitude towards his privileged status is only heightened by his indoctrination into the society of the just made perfect. When his father (and reverend) informs him that God has granted him salvation, Wrinhim openly welcomes his position as a justified person. In fact, the assurance of a heavenly reward only serves to further Wrinhim's twisted ideals. His beliefs become fanatical and his actions even more heinous.

At first glance, Wrinhim's approach to religion may seem like a farfetched excuse for immoral conduct or interpreted as a manipulation of doctrine. However, a closer look reveals that Wrinhim's beliefs are strongly rooted in Antinomianism, a theological following in which certain sects maintain that they do not have to abide by society's moral codes or laws. Likely to be a member of such a sect, Wrinhim comforts himself with the idea that salvation is predestined and that no amount of deeds or sins could alter his fate. Not only does this perspective place him at odds with other denominations but also with society as a whole which is governed by manmade laws. As a result of these competing principles, Wrinhim conveniently chooses to uphold his personal beliefs 
which allow him to exercise complete freedom. In developing this perverse sense of entitlement Wrinhim's toleration of other lay people begins to diminish. He remarks, an exaltation of spirit lifted me, as it were, far above the earth and the sinful creatures crawling on its surface; and I deemed myself as an eagle among children of men, soaring on high, and looking down with pity and contempt on the groveling creatures below (Hogg 104).

He further separates himself from the outside world and rejects any opinions that fail to coincide with his own.

Taking notice of Wrinhim's self-imposed isolation is crucial to understanding his predisposition to becoming a victim of Gil's rhetorical manipulations. His already enthusiastic and selfish beliefs are further exploited by Gil, a shape shifting character that fuels Wrinhim's ambitions. Wrinhim experiences an unexplainable magnetic attraction to this stranger. He recounts, "I felt a sort of invisible power that drew me towards him, something like the force of enchantment, which I could not resist. As we approached each other, our eyes met and I can never describe the strange sensations that thrilled through my whole frame at that impressive moment" (Hogg 106). Wrinhim's seemingly mysterious gravitation towards Gil is explained by their shared religious convictions. Also an outcast, Gil praises Wrinhim's narrow-minded ideas that go by unchecked by society. However, Gil's interest in Wrinhim's principles turns out to be more than just a mere coincidence. Wrinhim learns that his new acquaintance possesses the ability not only to morph into any person but also to read the minds of his victims. It is precisely Gil's ability to anticipate doubts and concerns that eventually allows him to exercise ownership over Wrinhim's actions. 
Although Gil is endowed with supernatural powers his main source of manipulation spawns from his oratory skills. Gil's manner of speech is lucid and persuasive, his rhetoric comparable to that of a preacher who appeals to non-believers through the use of ethos, pathos, and logos. Initially, Gil's credibility as a servant of God allows him to take hold of Wrinhim's attention. In presenting himself as a committed believer and as a modest pupil of the faith, Gil is able to gain access into Wrinhim's life. When asked by Wrinhim whether he would like to join contemplation and prayer Gil enthusiastically answers,

Ah, you little know with how much pleasure I will accompany you, and join with you in your elevated devotions. Your state is a state to be envied indeed; but I have been advised of it, and am come to be a humble disciple of your; to be initiated into the true way of salvation by conversing with you, and perhaps of being assisted by your prayers (Hogg 107).

When analyzing this passage, it becomes clear that Gil engages Wrinhim with an extremely influential tone and language. He flatters Wrinhim by acknowledging his "elevated devotions" and places himself as a "humble disciple" who wishes nothing more than to learn from his enviable state. In constructing this power dynamic, Gil appeals to Wrinhim's pride and gains his trust. His ethos is buttressed by his honest speech and restrained representation of his beliefs and ideas. As Jay Fliegelman notes, the success of an orator is measured beyond his ability to persuade his listeners; a great orator is also skilled in exiting, animating, and impressing his audience (Fliegelman xxviii). When examining Gil's word choice and his gesticulation, it could easily be argued that he meets the standards of a great orator. Like any great rhetorician, Gil recognizes the superiority 
and importance of his audience which in turn allows Wrinhim to perceive him as a morally distinguished character.

Perhaps even more fascinating is the way in which Gil reestablishes his ethos. As his relationship with Wrinhim evolves Gil transforms from an innocent bystander into a figure of authority. The power dynamics shift drastically when Gil reveals his "true identity" and purpose for seeking out Wrinhim's company. Gil hints at the possibility that he might be the Czar Peter of Russia and entertains the idea that he is also one of God's warriors. Upon unearthing Gil's seemingly true identity, Wrinhim feels obliged to obey his commands and to treat this all-knowing character with respect and veneration. After hearing Gil's compelling story Wrinhim observes,

But I soon felt that, instead of being a humble disciple of mine, this new acquaintance was to be my guide and director, and all under the humble guise of stooping at my feet to learn the right. He had said that I was ordained to perform some great action for the cause of Jesus and His Church, and he earnestly coveted being a partaker with me (Hogg 115).

In unveiling his real cause for seeking out Wrinhim, Gil is able to move beyond the stage of trust and assume the role of a powerful master. His credibility as a speaker no longer relies on his humility or genuine interest in religion but rather on his superior standing. By accepting Gil's role as a "guide and a director" Wrinhim immediately demotes himself to a lesser position. He becomes a listener, dependant on Gil's orders and mysterious plan. Consequentially, this exchange of power prompts Wrinhim to surrender autonomy and authority both over his convictions and actions. 
As the novel progresses, Gil's rhetorical manipulations become more severe and obvious. Simultaneously, Wrinhim finds himself unable to distinguish his own ideas from Gil's suggestions. Gil's treatment is no longer one of respect or admiration but rather it transforms into a master-slave relationship. Gil's dominance over Wrinhim becomes an undeniably dangerous fact of this novel as Wrinhim's voice becomes compromised his commands. Gil's rhetoric which once consisted of flattery and implicit suggestions is substituted with terrifying threats and explicit commands. In other words, as the tone and language of Gil's rhetoric changes so do his messages. One of the most powerful passages in this novel entails a discussion in which Gil convinces Wrinhim to murder his own brother and father. The dynamics of this dialogue reveal Gil's newfound authority and Wrinhim's willingness to submit. The conversation between the two characters escalates as Gil casually comments, "I am now going to put His courage in the cause he has espoused to a severe test— to a severe trial at which common nature would revolt but he who is dedicated to the sword of the Lord must raise himself above common humanity. You have a father and a brother according to the flesh... they must both fall! It is decreed in the councils above that they must both fall by your hand" (Hogg 132). To this Wrinhim cries, "I will not reason with you on this head, mighty potentate, for whenever I do so it is but to be put down. I shall only express my determination not to take vengeance out of the Lord's head in this instance. It avaeileth not" (Hogg 132). At first Wrinhim is repulsed by Gil's idea and sternly refutes the command. However, as the conversation moves forward Wrinhim finds himself unable to articulate his attraction to the idea of murder. He disregards his initial reaction to the plan and finds himself trapped in Gil's rhetorical manipulation. Resigned, Wrinhim concludes: 
I am, most illustrious prince, wholly at your service. Show but what ought to be done, and here is the heart, to dare, and the hand to execute. You pointed out my relations, according to the flesh, as brands fitted to be thrown into the burning. I approve peremptorily of the award; nay. I thirst to accomplish it; for I myself have suffered severe from my brother's diabolical arts. When once that trial of my devotion to the faith is accomplished, then be your future operations be disclosed (Hogg 141).

Gil's rhetorical manipulations have an immediate effect on Wrinhim's moral convictions and emotions. Through the use of pathos, Gil convinces Wrinhim that these orders will serve to further God's mission while granting him the possibility to vindicate his personal sufferings. In doing so, Gil is able to persuade Wrinhim to commit an immoral act according to manmade and God mandated laws. At first Wrinhim hesitates to accept Gil's plan as one that would be commended by God. However, within a matter of moments Wrinhim transforms from a stern and unwavering man into a repenting soul. His fear of disappointing Gil leads him to disregard his own discomfort with the plan and to embrace his role as a murder. His sudden willingness to commit the crime is both astonishing and compelling. In fact, Wrinhim's eagerness to appease his 'illustrious friend" manifests itself in his speech. His voice becomes filled with anticipation, his tone elated, and his language analogous to that of a warrior. This rapid conversion confirms the effectiveness of Gil's rhetorical abilities and the degree to which he influences Wrinhim's motivations. Interestingly, this passage also reveals a moment of selfawareness in which Wrinhim recognizes the extent to which Gil controls his mind. Wrinhim's only defense against Gil is to literally shut out his voice. In refusing to listen 
to Gil's reasoning, Wrinhim grants himself the possibility of escape. Unable to flee from Gil's presence, Wrinhim is powerless to resist the power of persuasion. As a result, Wrinhim is once again lured into obedience.

In order to better comprehend Gil's role within the narrative it is essential to explore the significance and implications of his shape-shifting abilities. Gil's tendency to adopt the appearance of multiple characters causes Wrinhim to question his ability to discern reality from the imagination. Similarly, Gil's identity as a doppelganger causes confusion for the reader who struggles to separate Wrinhim's actions from that of his counterpart. As a doppelganger, Gil represents a dangerous double that ruins his victims by framing them for crimes or other immoral actions. Given Gil's fluid identity, both the reader and narrator develop an obscure and incomplete notion of accountability. As Wrinhim's relationship with Gil evolves he finds himself unable to recall on his own whereabouts. Townspeople begin to accuse him of rape and murder yet Wrinhim has no recollection of committing such crimes. Empirical proof suggests that Wrinhim is indeed culpable of these crimes yet he denies the possibility of his involvement. Baffled by these incidents, Wrinhim seeks out Gil's council in hopes of arriving at a logical conclusion. However, Gil's explanation only further complicates both the reader's and the narrator's concept of a single truth. The following is an exchange between the two characters, If this that you tell me be true then is it as true that I have two souls. Which take possession of my bodily frame by turns, the one being all unconscious of what the other performs; for as sure as I have at this moment a spirit within me, fashioned and destined to eternal felicity, as sure am I utterly ignorant of the crimes you now lay to my charge. Asservation will avail you but little, answered he, 
composedly. It is however, justifiable in its place, although to me it signifies nothing, who knows too well that you did commit both crimes, in your own person, and with your own hands. Far be it from me to betray you; indeed I would rather endeavor to palliate the offences; for though adverse to nature, I can prove them not to be the cause of pure Christianity, but the mode of which we have approved of it, and which we wish to promulgate (Hogg 173-174).

Once again, this passage highlights Gil's argumentative skills. Rather than to provide a logical solution to this misunderstanding he suggests that the body and mind can function as separate entities. Gil steers Wrinhim away from any doubts and forces him to accept responsibility for the violent murders. At this point in the narrative, Gil's rhetorical manipulations have taken full control over Wrinhim's ability to rationalize. As a speaker, he has mastered the three rhetorical appeals of ethos, logos, and pathos. Early on in the narrative, Gil builds a sense of trust with Wrinhim by appealing to his pathos. Gil's use of guilt, flattery, and concrete language evoke an emotional response in Wrinhim's character. Similarly, Gil is able to influence Wrinhim's actions by establishing his authority as a recipient of God's will. By developing his ethos, Gil is able to assert the dominant role and persuade Wrinhim into adopting his views and ideas. Gil's cunning nature and exceptional talent as a rhetorician leap from the pages of this novel. The ease with which he is able to convince Wrinhim of his culpability is both admirable and frightening. Gil's use of logos is irrefutable, causing Wrinhim to further rely on him for an interpretation of the mysterious and seemingly supernatural occurrences. As a result, Wrinhim is faced with an overwhelming amount of empirical proof indicating that his involvement with the crimes is a fact and not a debatable issue. 
Gil's explanation of the events leaves Wrinhim feeling bewildered and unable to distinguish reality from the imagination. Similarly, the dissonance between these two accounts forces the reader to reassess their trust in the narrator. Gil's ability to provide both a logical and coherent explanation to the strange occurrences appeals to the reader's desire for closure. Not only do Gil's rhetorical manipulations affect Wrinhim's viewpoint but also the reader's ability to arrive at a single truth. Much like Wrinhim (who is seduced by Gil's promise of a heavenly reward) the reader is lured by Gil's ability to provide clarity within the narrative. Essentially, both Wrinhim and the reader become victims of Gil's rhetorical manipulations and malignant agenda.

While Confessions explores the effects of visual manipulations, Wieland delves into the consequences that result from imagined and misinterpreted authority. Brown's novel also analyzes the correlation between religious enthusiasm and auditory seduction. Much like Wrinhim, Wieland is depicted as a man who searches for empirical proof of God's existence within the physical world. Eager to receive confirmation of God's will, Wieland invests the great majority of his time reading scripture. Said to have inherited his father's fanaticism, Wieland is clearly predisposed to being subdued by mysterious occurrences and supernatural forces. Clara, the narrator, describes her brother as being a "grave, considerate, and thoughtful" man whose studies consist of Calvinistic inspirations and determinist viewpoints. However, unlike his father Wieland balances his passion for religion with a healthy appetite for science and philosophy. Clara notes the following regarding her brother's demeanor,

In his studies, he pursued an austere and more arduous path. He was much conversant with the history of religious opinions, and took pains to ascertain their 
validity. He deemed it indispensable to examine the ground of his beliefs, to settle the relation between motives and actions, the criterion of merit and the kinds and properties of evidence (Brown 26).

Not only does Wieland suggest that God exists but he also strives to prove the validity of this hypothesis with measurable evidence. In other words, Wieland seeks to provide physical, logical, and conclusive proof for the supernatural. It is this unlikely combination of secular and theological beliefs that prompt Wieland to entertain the idea of disembodied voices. Seeing that the voices could be interpreted as physical manifestations of God's will, Wieland becomes easily seduced and manipulated. Whereas denying or questioning the logic of such occurrences would void his faith.

Upon hearing the disembodied voice for the first time, Wieland is left feeling both exalted and perplexed. The circumstances in which he encounters this phenomenon only add to his curiosity and frantic approach. Alone in the midst of the woods, Wieland is suddenly startled from his mediations as he hears the voice of his wife. He recounts, I had ascended the hill little more than half way, when a voice called me from behind. The accents were clear, distinct, and powerful, and were uttered as I fully believed by my wife. 'Stop, go no further. There is danger in your path.' The suddenness and unexpectedness of this warning, the tone of alarm which it was given, and above all, the persuasion that is was my wife who spoke, were enough to disconnect and make me pause (Brown 37).

Similar to Wrinhim, Wieland experiences an unexplainable desire to obey the commands emanating from the voice. While Wrinhim is mesmerized by Gil's ability to persuade, Wieland is subdued into submission by the voice's "clear, distinct, and 
powerful tone". In fact, Wieland is convinced that the warning must have been issued by his wife seeing that there is an unmistakable resemblance in tone and accent. However, the lack of physical evidence should have prompted Wieland to question this implication. As a man of science Wieland should have questioned the reliability of his senses. Yet, as a man of faith, the presence of a voice and the absence of a body serve as potential proof for the existence of a supernatural entity. Although Wieland does not express these conflicting views, it becomes apparent that he is both vulnerable and easily seduced by the unknown. His innate impulse to comply with the warning mirrors Wrinhim's willingness to relinquish his autonomy. Wieland entertains the possibility that the voice has a source although his senses suggest otherwise. In trusting the voice's commands Wieland becomes subservient to an invisible authority.

As the narrative progresses, the Wieland family comes to assume that the voice is not a byproduct of a physical entity. The notion of a disembodied voice creates havoc in this once organized and complacent community, resulting in conflicting explanations for the strange occurrences. While Clara is thrilled and intrigued by these miraculous manifestations, Wieland reacts in a much more somber manner. Clara notes the following of her brother, "This new incident had a visible effect in augmenting his gravity. He was less disposed to than formerly to converse and reading. When we sifted his thoughts, they were generally found to have relation, more or less direct, with this incident. It was difficult to ascertain the exact species of impression which it made upon him" (Brown $40)$.

Clara's observations indicate that the voice has had a powerful impact on her brother, transforming the already somber character into an introverted individual. Unable 
to arrive at a logical conclusion, Wieland retreats in hopes of finding an explanation for the disembodied voice. Already predisposed to being an enthusiast, Wieland's encounter with the voices further encourages him to rely on his religious convictions. The voice symbolizes a privileged type of communication where Wieland is at times the sole recipient of its commands. Wieland's desire to prove the existence of the supernatural leads him to believe that the voice might eliminate the need for interpretation. Wieland no longer relies on having to deduce God's will from scripture or other secondary mediums. Instead, the vocal delivery of these messages provides Wieland with an immediate reassurance of his faith. The effect that the voice has on Wieland is similar to the control that Gil exerts over Wrinhim. Gil's rhetorical abilities seduce Wrinhim into neglecting his previous dedication to sermons and prayer. As a result of this narrowminded approach, Wrinhim is unable to differentiate his thoughts from Gil's commands. Wieland's state of isolation also mirrors Wrinhim's self-imposed exile in which private thoughts take precedence over societal codes. Comparable to Wrinhim (who strives to please Gil), Wieland becomes dependant on the commands that are issued by the mysterious voice. The voice represents a new form of rhetoric, one in which the speaker has no physical presence. Given its nature, the voice is interpreted as a force that should be respected and obeyed. In accepting this power dynamic, Wieland relinquishes his autonomy (as an independent thinker) and grants the voice authority (both over his physical body and his thoughts).

The theme of authority misinterpreted and authority imagined is discussed in great detail in Looby's Voicing America. Looby notes that the characters feel obliged to obey the voice for two reasons, 1) the voice produces action and 2) the voice speaks 
mostly in the form of a command. The disembodied voice creates a pattern of "causal order" in which the listener is subdued into obedience. Wieland and Clara come to view the voice as a reliable source of knowledge due to its uncanny ability to predict the future and provide useful warnings. This leads the Wieland family to develop a sense of trust in the voice, expecting that its messages will manifest into actions. Looby explains, "Everything happens because of voices and the words and noises carried by those voices" resulting in a codependency between the speaker and the listener (Looby 150). After realizing that the voice can produce material results, Wieland no longer questions or doubts its authority. The ethos of this voice is supported by its correlation between words and the manifestation of actions; metaphorical expressions become actualized in the physical world. As the voice becomes more vocal and recurrent, the content of its messages begin to shift.

Once perceived as a cautionary force, the voice begins to instill fear and confusion in the Wieland family. It could be argued that the voice transforms from a supernatural guide into a menacing force. No longer suggestive, the voice commands control over Wieland through declarative statements and commands. "Hold!", "You shall not go", and "Stop, Stop" are all commands spoken by the disembodied voice. Seduced by the possibility that the voice might be representative of God's will, Wieland proceeds to obey without hesitation. Wieland's lack of resistance allows the voice to progress onto the next stage of rhetorical manipulation. The voice threatens to physically harm characters such as Clara thereby suggesting its ability to translate warnings into acts of violence. Not only do these threats alarm Clara but they also force her to question her ability to discern reality from the imagination. Upon hearing voices plot her murder Clara 
remarks, "I revolved every incident and expression that occurred. My senses assured me of the truth of them. And yet their abruptness and improbability made me, in turn, somewhat incredulous" (Brown 67).

While Clara's hearing confirms the validity of the threat her vision insists that there is no physical body to carry out the intended crime. These conflicting sensory experiences instill even more fear and awe towards the voice. Looby writes, "The one true world which is a requisite condition for social life finds one of its necessary conditions in our ability to distinguish among voices, assign voices to bodies, and locate voices in space and time" (Looby 166-67). Unable to make this distinction, Clara wrestles with the possibility that the voice might originate from a physical source. Ultimately fear of the unknown trap Clara and Wieland into a position of vulnerability and submissiveness.

Once the true identity of the disembodied voice is revealed, both Clara and Wieland come to realize the extent of their susceptibility. Unaware of the dangers that lurk within their own residence, the Wieland family fails to question the source of the voice. The desire to obey combined with their willingness to submit renders them powerless to analyze their surroundings. As a result, obvious and discriminating evidence goes by unnoticed by the narrator as she continues to accept the voice as a supernatural occurrence. Unaware that their newly arrived friend Carwin possesses the gift of ventriloquism, the Wieland family never considers him a suspect. However, Carwin's eloquent tone and magnetizing rhetoric suggest otherwise. In fact, Clara is amongst the first to experience an unexplainable pull towards Carwin's voice. She remarks, 
He was sparing in discourse; but whatever he said was pregnant with meaning, and uttered with rectitude of articulation, and force of emphasis, of which I had entertained no conception previously to my knowledge of him. He uttered no sentiment calculated to produce disadvantageous impression: on the contrary, his observations denoted a mind alive to every generous heroic feeling. They were introduced without parade, pained with that degree of earnestness which indicated sincerity (Brown 82).

In the passage above, Clara equates genuine emotion (pathos) with the credibility (ethos) of the speaker. She comments on Carwin's effortless ability to persuade his listeners as well as his captivating articulation and "force of emphasis" (Brown 82). Jay Fliegelman comments on the seductive nature of Carwin's rhetoric and the immediate effect that it has on Clara. He explains that the power of eloquence rests in the speaker's ability to choose particular tones, gestures, and facial expressions that will achieve the desired reaction from the listener (Fliegelman $\mathrm{xxx}$ ). Not only is Carwin selective with his diction but he is also careful with the way in which he constructs and presents his messages. Fliegelman compares Carwin's modest yet talented manner of speech to that of "natural language" in which the speaker is commended for his ability to "communicate pure emotion from one heart to another unmediated by the head" (Fliegelman xxxi). Carwin is able to gain Clara's trust and respect by aligning himself with this mode of speech. His lack of artificiality combined with the transparency of his language enable his manipulations to go by unnoticed.

As the novel draws to an end, it becomes apparent that Carwin utilizes his rhetorical abilities as a means to dishevel the Wieland household. It is Carwin who, 
unbeknownst to his victims, exploits his gift of ventriloquism to manifest the mysterious voices. This dangerous and unique oratory skill allows Carwin to project and imitate the voices of others. In Voicing America, Christopher Looby explains how Carwin's ventriloquism distorts the notion of authority by exerting invisible power. Once a peaceful and self-governed community, the Wieland compound is seduced by an external force that exhibits supernatural powers. Carwin's vocal deceptions contradict empirical evidence thereby suggesting a possible manifestation of God's will. Moreover, the voice confuses the characters' ability to derive logical and coherent information from their sensory experiences. Looby argues that the "elementary structures of everyday experience" are disrupted when one's hearing and seeing is misaligned (Looby 166). Carwin's voice makes identification difficult, if not impossible at times, causing characters such as Clara and Wieland to question their mental capacities. The overall result of ventriloquism is the demise of these disoriented characters who struggle to distinguish the physical from the imaginary.

The extent to which Carwin comes to control Wieland is perhaps best illustrated in the final chapters of the novel in which Wieland brutally slays his family. Already emotionally and psychologically distressed, Wieland turns his thoughts to the fate of his family. While contemplating, Wieland is once again interrupted by the mysterious voice. Startled by its apparition, Wieland carefully listens to the bearer of news. He recounts, "As it spoke, the accents thrilled to my heart. 'Thy prayers are heard. In proof of thy faith, render me thy wife. This is the victim I chuse. Call her hither, and here let her fall"' (Brown 190). At first Wieland attempts to dissuade the voice from its commands only to realize that his efforts were "In vain. The conditions were prescribed; the decree had gone 
forth, and nothing remained but to execute it" (Brown 190). His inability to regain autonomy or to reject the command suggests that Wieland willingly relinquished authority over his actions. Like Wrinhim, Wieland is driven to a state of delusion where the motives for his actions are unclear and debatable. Both characters argue that their final crimes were motivated by an external source yet the evidence suggests another possibility. As the characters reexamine the reliability of their sensory experiences, the reader begins to cast doubt upon Wieland's interpretation of events. Their shared religious enthusiasm and ominous outlook on reality raise the question whether the imagination is mistaken for divine revelation. Wieland's desire to obey God's commands and prove the existence of a supernatural force interjects with his ability to persuade the reader of his innocence. Voices distort the coherency of the narrative, resulting in an inconclusive ending where the reader is free to judge Wieland as an innocent victim of circumstances or as a deranged enthusiast. Regardless of the reader's interpretation, the impact that the voice has on the Wieland household is undeniable.

\section{Authorial Authority}

Another recurring theme in these novels is the power of the written word. Although the spoken word carries great weight in terms of persuasion, the written word also exerts rhetorical power over the reader. While the dialogue in these narratives has an immediate effect on the listener, the written word has a similar gripping effect on the reader. Characters are wooed into submission by speech whereas the reader is influenced by the words that appear on a page. Arguably, the power dynamics between writer/reader and speaker/listener are very much the same. The reader and the listener accept their role as recipients of information and are subject to the speaker's or writer's intent. Thus, when 
analyzing the role that rhetoric plays in the works of Wieland and Confessions it is important that we also acknowledge the physical manifestation of the author's thoughts and ideas. As the composer of the text, the author exercises both power and authority over the reader. Although the genre of Gothic fiction promotes an interactive experience between the text and the reader, the author's control over the narrative cannot be overlooked. From producing misleading title pages to compelling advertisements, the author shapes the reader's response to the text. Much like Carwin and Gil who utilize ethos, pathos, and logos to convince their counterparts, Brown and Hogg employ these rhetorical appeals to appeal to the reader.

Brown establishes his authority from the very beginning, by providing his readers with a moral to his story. The epigraph on the title page reads, "From Virtue's blissful paths away the double-tongued are sure to stray; Good is a forth-right journey still and mazy paths but lead to ill" (Brown 1). These words set the tone for the rest of the narrative, in which characters are faced with the task of discerning truth from the imagination. Brown's subtle hints suggest that "double-tongued" individuals will inevitably stray away from the path of virtue. Here, Brown refers to the art of ventriloquism, where the speaker fails to be forthright in terms of his identity and the message that he delivers. As a result of this doubleness, one is no longer able to trek a forth-right journey. Brown likens the path of singularity and righteousness to one that is blissful and simple. On the other hand, he condemns the deceitful to a "mazy" path of uncertainty.

This brief inscription serves to forewarn readers of the dangers of falling victim to rhetorical seduction. Brown associates open spaces with the ability to speak freely and 
honestly. Simultaneously, he equates ventriloquism with the constriction of language both in terms of physical space and human physiology. As a ventriloquist, Carwin confined to small areas (such as Clara's closet) to keep his identity secret. In addition, ventriloquism requires Carwin to utter his messages in a voice that is not his own. As a result, not only is the identity of the voice compromised but also the reliability of its message. With this, Brown argues that the "double-tongued" represent danger and obscurity. He sets the stage for the reader and builds up their expectations of encountering examples of both virtuous and vile characters. The epigraph makes the reader aware of the theme that Brown chooses to highlight. It places the author in a position of authority and the reader in a state of a listener.

Brown further exercises his role as a figure of authority in the advertisement to Wieland. Here, he explains the purpose of writing this piece and the effect that he hopes it will have on the public. It is in this brief section that Brown's aim to influence the reader is made evident. Through the use of ethos, Brown reassures his audience that his purpose is "neither selfish nor temporary, but aims at the illustration of some important branches of the moral constitution of man" (Brown 3). By presenting himself as a humble author who seeks to merely educate the masses, Brown gains entry into the minds of eager readers. In claiming that his intentions are neither "selfish nor temporary", Brown comes across as a trustworthy author.

Brown also utilizes pathos, or a strong emotional appeal, to captivate the attention of his audience. He writes, whether this tale will be classed with the ordinary or frivolous sources of amusement, or be ranked with the few productions whose usefulness secures to them a lasting reputation, the reader must be permitted to decide" (Brown 3). He 
dismisses his authorial authority and invites the reader to judge the moral and intellectual worth of his novel. Like Gil, who seduces Wrinhim through flattery, Brown seduces his reader by bestowing interpretative power upon them.

Midway through the advertisement, Brown makes an appeal to the reader's logic through the use of logos. He explains that although the incidents related might seem extraordinary or rate, their veracity can be traced back to a similar case. Brown writes, "if history furnishes one parallel fact, it is a sufficient vindication of the Writer, but most readers will probably recollect an authentic case, remarkably similar to that of Wieland" (Brown 4). As the author of this novel, Brown realizes that readers may be tempted to dismiss the events as mere fiction. However, he frees the reader from this anxiety by presenting them with an original case in which a seemingly spiritual experience led to the massacre of a family. Brown likens the role of the writer to that of a painter. He explains that like moral painters, authors must choose to "exhibit their subject in its most instructive and memorable form" (Brown 4). In drawing this comparison, Brown assures the reader that the accounts will not stray from the known principles of human nature. The disembodied voices will be explained through the rational and natural act of ventriloquism. Thereby, the reader can entrust that the experiences described in this narrative derive from factual historical evidence.

James Hogg also establishes his authority as an author within the last section of Confessions. In this short and final piece, Wrinhim's remains are excavated by a group of writers. In this section, Hogg steps outside of the parameters of an author by situating himself within the narrative. Hogg becomes one of the characters that discover the manuscript of Wrinhim's confessions. In this strange turn of events, the reader must rely 
on Hogg to both narrate and format the account. Interestingly, by becoming the narrator Hogg is able to offer a wide variety of solutions to the perplexing confessions. What had been implicitly stated throughout the story could now be verbalized. Hogg pushes the reader to linger longer on the problematic nature of Wrinhim's account. He writes, "What can this work be? Sure, you will say, it must be an allegory; or (as a writer calls it) a religious parable, showing the dreadful danger of self-righteousness? I cannot tell" (Hogg 217). Hogg entertains the reader's possible explanations for the seemingly supernatural apparitions. However, he does not provide his audience with a single truth or answer to these questions. In doing so, Hogg maintains power over the reader. He privileges the obscurity that is upheld by the genre of Gothic fiction and entices his readers to revise and question their interpretations.

$\underline{\text { Testimonies and Confessions }}$

The narrators of Wieland and Confessions of a Justified Sinner rely on the testimonies of their counterparts to clarify their experiences with the supernatural. Unable to rely on their senses, Clara and Wrinhim deem themselves incapable of sorting reality from the imagination. Unfortunately, their state of helplessness serves to only further their codependency to Gil and Carwin. Not only do Clara and Wrinhim relinquish their moral authority by creating these relationships but they also compromise the coherency of the narratives. This section will examine the nature of testimonies and confessions and analyze the ways in which characters such as Gil and Carwin manipulate the narrator's interpretation of events.

Literary critic, Jane Hinds, marvels at the impenetrable layers of discourse that can be found in the novels of Charles Brockden Brown. She writes, "Placed within either 
a literal or figurative wilderness, Brown's narrators find themselves unable to construct narrative without chaos, unable to conform stories to conventional fictional structures. They produce instead discursive forms of terror-inspiring coherence" (Hinds 109). Not only is the Wieland family physically isolated from society (presumably situated in the wilderness) but they are also faced with unusual and "wild" phenomenon. As the narrator, Clara attempts to distance herself from the chaos in hopes of delivering a logical and coherent narrative. Unable to rely on her own reasoning, Clara introduces multiple voices and testimonies into the narrative. From early on in the narrative, Clara is predisposed to relying on the testimony of others as a resource for knowledge. In fact, Clara attempts to present herself as a reliable narrator by providing readers with firsthand accounts from credible sources. These "factual" testimonies allow Clara to report certain events without necessarily having to witness or experience them. As Clara recounts the events leading up to her father's spontaneous combustion she introduces her uncle's testimony. Unable to recall on her own memory, Clara is forced to rely on her uncle's interpretation of the tragic evening. She writes,

The preclusive gleam, the blow upon his arm, the fatal spark, the explosion heard so far, the fiery cloud that environed him, without detriment to structure, though composed of combustible materials, the sudden vanishing of this cloud at my uncle's approach - what inference to be drawn from these facts? Their truth cannot be doubted. My uncle's testimony is peculiarly worthy of credit, because no man's temper is more skeptical, and his beliefs in unalterably attached to natural causes (Brown 21). 
Since Clara was not present at the time of the incident she looks to her uncle for a logical explanation. By characterizing him as a trustworthy and morally upright individual, Clara suggests that her uncle is more than qualified to relate the order of events. However, the effect that this testimony has on the reader is quite the opposite. Clara's efforts to authenticate her uncle's testimony come across as desperate and forced. Her longing for closure seems to prevent her from even questioning the validity of the account. Unable to make sense of her father's death, Clara decides to rely on her uncle's testimony in hopes of filling in the gaps of knowledge. Clara's quickness to accept this version and her unwillingness to probe any further indicate the ease with which she can be convinced. Not only does Clara treat the testimony as factual but she also presents it as her own. In other words, Clara adopts her uncle's viewpoint by allowing it to shape the memory of her father's death. She writes, "The impressions that were made upon me can never be effaced. I was ill qualified to judge respecting what was then passing; but as I was advanced in age, and became more fully acquainted with these facts, they oftener became the subject of my thoughts" (Brown 21). Even though she was not an eyewitness to these events she claims that the vents had a lasting "impression" on her. Clara assimilates her uncle's testimony to the point where the reader realizes that she is relating it as her own. Looby adds, "The impressions or facts are in truth, functions of discursive accounts of those putative facts; they are, quite without exception, the products of reconstructive inference from those discursive representations. The rest of the novel repeats this model: from words, voices, and testimony, Clara draws inferences, and from them she points to facts and recalls impressions (Looby 154). Clara's inability to separate herself from her uncle's testimony leads her to mistake opinion for facts. As Looby notes, Clara's naivety 
and confidence in the discourse of others affects the way in which she perceives her past as well as her immediate reality.

Like Clara, Wrinhim utilizes the testimony of others to support his claims. Unable to draw inferences from his personal experiences, Wrinhim is forced to rely on Gil's interpretation of events. As the narrative progresses, his dependency on Gil only escalates. In the final stages of his confessions, Wrinhim is incapable of discerning his own recollections from that of his counterpart. Magdalene Redekop claims, "The more paralyzed Wrinhim becomes, the more his narrative allows invasion of outside perspectives. Helpless to comprehend himself, he simply records, verbatim, what others say" (Redekop 174). Wrinhim sacrifices the possibility of a "single truth" by allowing outside perspectives to invade the space of his narrative. As a result of this crowded and convoluted narrative, Wrinhim's credibility and innocence are oftentimes questioned.

A prime example of Wrinhim's excessive trust can be found in one of the most pivotal scenes of the narrative. Gil's final test of faithfulness requires Wrinhim to murder his brother. Certain that this act will prove his loyalty to God, Wrinhim prepares for the battle. However, as the day approaches Wrinhim's confidence and willingness to murder begin to fade. On the night of the attack, Wrinhim refuses to carry out the plan and begs Gil for forgiveness. Unwilling to spoil the opportunity, Gil commands Wrinhim to accompany him and to follow all orders. The chains of events that follow are murky and incomprehensible both for the reader and the narrator. Wrinhim denies having partaken in the murder and claims to have been simply a witness to the attack. On the other hand, Gil argues that the victory was a result of a joined effort and commends Wrinhim for his support. Unable to distinguish fact from a skewed point of view, Wrinhim decides to 
adopt Gil's explanation. He writes, "I will not deny that my own immediate impressions of this affair in some degree differed from this statement. But this is precisely as my illustrious friend described it to be afterwards, and I can rely implicitly on his information, as he was at the time a looker-on, and my senses all in a state of agitation, and he could have no motive for saying what was not the positive truth" (Hogg 155). The quickness with which Wrinhim accepts Gil's testimony is both concerning and confusing. Having witnessed the murder, Wrinhim should have been able to deduce information on his own. However, his decision to incorporate Gil's account into the narrative demonstrates the severity their codependent relationship. Wrinhim defends Gil's testimony by arguing that his "illustrious friend" had no motive to provide biased information. Wrinhim's naiveté combined with his unwavering trust in Gil indicate his willingness to abandon autonomy and to adopt a state of submissiveness. Like Clara, Wrinhim worries that his bewildered senses and "state of agitation" would interfere with his ability to arrive at a logical and coherent solution. It is precisely Wrinhim's distrust in his own judgment that prompts the reader to question the validity of the narrative. As a result, one is unable to ascertain whether Wrinhim is culpable of committing the horrific crime or if Gil has manipulated his viewpoint. Comparable to Wieland, Wrinhim's verdict is left in the hands of the reader, his innocence to be determined by one's interpretation of the events.

A close look at these novels unveils the great emphasis that Brown and Hogg place on rhetorical manipulations. The art of oration and the theme of speech as a marker of power are explored in great detail by these two authors. While Wieland focuses on vocal deception and trickery, Confessions analyzes the argumentative skills of a 
supernatural entity. Both Gothic fiction writers present artful speaking as a threatening trait that has the power to destroy and seduce others. Perhaps even more interesting is the way in which these authors illustrate the correlation between rhetoric and religious enthusiasm, where eager listeners transform into victims and speakers into God-like figures. In examining the power dynamic between listener and speaker, Hogg and Brown help shed light on the dangers of self-imposed submissiveness and misinterpreted authority 


\section{HEIGHTENED SENSES}

\section{The Tension between Religious Enthusiasm and Divine Revelation}

Charles Brockden Brown and James Hogg explore the dangers of religious enthusiasm by presenting readers with characters who are unable to distinguish reality from their imagination. In fact, their characters are oftentimes depicted as delusional individuals who mistake religious fervor for divine revelation. Gothic novels such as Wieland and Confessions of a Justified Sinner portray religion as a seductive force that has the potential to distort (if not destroy) human reasoning. The first novel takes a close look at the repercussions of religious fanaticism while the latter analyzes the ways in which salvation is misused as a justification for sins. Both works demonstrate how the desire to submit to a higher power requires one to relinquish moral authority and autonomy. Characters like Wrinhim and Wieland are used to exemplify the fine line that separates genuine religious experiences from enthusiastic interpretations. Their narrowmindedness combined with their outlandish religious convictions make them vulnerable to becoming victims of fanaticism. Wieland's determination to prove the existence of a supernatural entity prompts him to abandon his once level-headed approach for a much more extremist point of view.

Similarly, it could be argued that Wrinhim's longing to know God's will leads him to develop a skewed understanding of Christian atonement. The striking similarities between these two novels suggest that enthusiasm was indeed a controversial and pertinent topic of early $19^{\text {th- }}$ century Anglo-American culture. The tension between religion and logic is clearly verbalized by authors such as Brown and Hogg who scrutinize the validity of religious experiences. This chapter aims to unravel the complex nature of religious fervor by examining the philosophical and theological roots of this 
issue. In doing so, I hope to offer a better understanding of the power struggle that exists between revelation and enthusiasm.

In order to examine the role of religious enthusiasm in the texts of Brown and Hogg it is necessary that we recognize the difference between a genuine spiritual awakening and a misinterpreted experience. From as early as the sixteenth century, the term "enthusiast" was used to describe individuals who veered away from Christian orthodox principles in search of a more liberal approach. This pejorative connotation caused many to view enthusiasts as a threat to the structure and authority of organized religion. Their dismissal of traditional worship combined with their heavy emphasis placed on personal interpretation caused rifts amongst various religious denominations. Arguably, this term became widely popularized and disseminated throughout the eighteenth century religious revivalist period known as the Great Awakening. This transatlantic movement vigorously swept across the British Empire and North America, introducing innovative theological perspectives. Although each state and nation was affected differently, the underlying purpose of this religious movement was to bring about transformation in the relationship between church and the individual (Lovejoy 186). The power dynamics shifted so that in most cases an individual was granted the power to interpret the meaning of their spiritual awakening, divine revelation, or salvation. Rather than to rely on a minister or priest to decipher a spiritual experience, individuals were encouraged to develop intimate relationships with God. Emotions and zeal were seen as desirable traits in an individual's spiritual awakening. In fact, advocates of the Great Awakening claimed that "enthusiasm was a remarkable outpour of God's 
grace" (Lovejoy). As a result, emotions and affections became markers of a spiritual enlightenment.

However, the term "enthusiasm" did not fully manifest itself in European culture up until the mid seventeen hundreds. In 1730 Calvinist minister, Jonathan Edwards preached the message that salvation was only possible through the grace of God. In doing so, an unparalleled emphasis was placed on the importance of the individual. Edwards maintained that the individual conversation experience served as evidence of the person's state of grace. In other words, no amount of good deeds, prayer, or church attendance could override God's sovereignty (Lovejoy 187). Edward's message that salvation was only possible through the grace of God was adopted by various religious extremists. As a result, many of his contemporaries misinterpreted the emphasis on the individual as the privileging of private worship. Without the presence of an external authority, individuals were free to interpret their experiences. Enthusiasts claimed that theology and church order were unnecessary when interpreting the will of God. Lovejoy highlights the difference between enthusiasm and revelation claiming,

In their drive to know God, the come-outers were impatient with the confines of theology and ecclesiasticism, and they constantly sought a more direct, intense, and personal relationship with God. Enthusiasts found rash action necessary for defying traditional religious restraint, and insisted on emotional involvement in their search for righteousness (Lovejoy 2).

When analyzed closely, the tug of war between the critics and proponents of the Great Awakening is made clear. Opponents argued that excessive emotions, personal interpretations, and direct contact with God were signs of "enthusiasm" while supporters 
of this revivalism maintained that affections and intimate relationships with God were true signs of spiritual enlightenment. It is precisely this tension that is verbalized in the texts of Brown and Hogg. In fact, both Wieland and Confessions highlight the complexity of these definitions by having their characters exhibit traits that can be interpreted as enthusiastic or as genuine conversions. In using these terms interchangeably, both Brown and Hogg stress the difficulty that one is faced with when trying to distinguish a credible religious awakening from a misinterpreted experience.

In Wieland, the reader is introduced to characters whose experiences can be either described as enthusiastic or as legitimately spiritual. As the narrator Clara explains, how her family's tranquility has been disrupted by strange occurrences and supernatural-like apparitions. She explains the degree to which her father's mysterious behavior and ominous religious principles affect her and her brother's perception of reality. Clara describes her father as a man who at an early age adopted a "morose and gloomy" outlook on life. As an apprentice, he was left with little recreational time which only aggravated his already complicated state of mind. Overcome by dissatisfaction, Wieland Senior finds himself yearning for a purpose. It is precisely with this restlessness and susceptibility that Wieland happens to stumble upon the religious tracts of Camisssards. Clara presents this moment in the following way,

One Sunday afternoon, being induced to retire for a few minutes to his garret, his eye was attracted by a page of the book, which, by some accident, had been opened and placed full in his view. He was seated on the edge of his bed, and was employed in repairing a rent in some part of his clothes. His eyes were not confined to his work, but occasionally wandered, lighted at length upon the page. 
The words "Seek and ye shall find", were those that first offered themselves to his notice. His curiosity was roused by these so far as to prompt him to proceed. As soon as he finished his work, he took up the book and turned to the first page... his mind was in a state peculiarly fitted for the reception of devotional sentiments. The craving which had haunted him was now supplied with an object (Brown 89).

This quote raises some thought-provoking questions regarding Wieland's unsuspected interest in religious writings. His "chanced" encounter with the book can be interpreted as either a) a manifestation of a higher power or b) an indicator of his tendency to engage in enthusiastic behavior. Clara's tone and presentation of the events suggest that Wieland's experience was indeed involuntary. She describes him gravitating towards the book, as if though he had been predestined to see the words "seek and ye shall find". Strangely enough, the words on the page resonate with Wieland's longing for a greater purpose. The book seems to provide an answer to Wieland's disillusionment with his lifestyle. By emphasizing the unexpected and immediate effect that the phrase had on Wieland, Clara leads the reader to believe that Wieland experienced a profound religious enlightenment. His eagerness to continue reading and curiosity towards the subject manner could easily support the contention that Wieland underwent a spiritual conversion

Yet, when analyzed carefully this quote reveals Wieland's propensity to religious enthusiasm. The emphasis that is placed on the accidental nature of this event is both troubling and suspicious. Clara repeatedly uses words such as "accidental", "wandered", and "peculiarly" so as to diminish Wieland's control over the situation. She describes the 
book as a seducer, enacting agency and authority over Wieland. As a result, Clara's rendition comes across as inauthentic and forced. Wieland's "state of mind" should be taken into consideration and regarded as a precursor. In other words, the text serves to satisfy his preexisting "cravings". Wieland's willingness to accept the doctrine and to abide by its principles makes him susceptible to religious enthusiasm. Rather than to interpret this as a mysterious (or potentially supernatural) occurrence the reader should analyze Wieland's inclinations. Upon reading these religious tracts, Wieland's aimless search for a purpose finally comes to an end. As Clara writes, "The craving which had haunted him was now supplied with an object" (Brown 9).

Prior to his encounter with the Protestant doctrine, he had no spiritual vocation and showed no interest in learning the word of God. It is only when Wieland realizes that religion could fill his void that he becomes a fanatic. The prescriptive nature of religion provides him with an object to fixate upon. Prayer and reading Scripture grant Wieland a sense of satisfaction. The repetitive nature of these acts seems almost like a manifestation of a compulsion. Clara describes her father as being obsessed with the impeccability of his actions. After reading the doctrine of Camissards, Wieland appears to be unable to behave or think in any fashion that contradicts its teachings. Clara describes him in the following manner, "His moral which had never been loose, were now modeled by a stricter standard. The empire of religious duty extended itself to his looks, gestures, and phrases. All levities of speech, and negligence of behavior, were proscribed" (Brown 10). As a result of the drastic change in Wieland's behavior, the question arises whether his encounter with the text was accidental (provoked by a supernatural force) or self-created. The uncanny nature of this scene further highlights the tensions that arise 
when trying to differentiate the intervention of a higher being from the imagination. In fact, the scene provides little to no clarification in regards to the validity of Wieland's experience. While Wieland is described as being unaware of the content or import of the text, his actions seem to be driven by his desire to find a purpose or a preoccupation. In this case, the text becomes the effect of Wieland's cause. His hasty interpretation of the text along with his enthusiasm of its message buttresses such a reading. On the other hand, the emphasis that is placed on the uncontrollable nature of Wieland's response to the text is worth analyzing. Clara describes her father as being lured by the book and seduced by its content. She notes, "The further he read, the more inducement he found to continue, and he regretted the decline of light which obliged him for the present to close it" (Brown 9). Not only is Wieland depicted as being possessed by a yearning desire to learn more about the teachings of Camissards but he is also shown as having no control over his reaction. Wieland's unexpected emotional reaction to the text creates anxieties as to whether his experience is truly that of a spiritual enlightenment. Once again, the ambiguity of this episode problematizes the line that separates religious enthusiasm and a genuine spiritual conversion.

As the narrative develops, the tension between private and public worship becomes a recurrent theme as Wieland's affections become less rational and more dogmatic. Being a hermit, Wieland refuses to balance his religious interpretations with the guidance of an external authority. Like many enthusiasts of the $18^{\text {th }}$-century, he chooses to engage in private worship in hopes of retaining authority over his religious experiences. However, Clara notes that her father's isolation only furthers his skewed perspective of Scripture. The writings of the Camisard apostle became Wieland's 
obsession. Overpowered by his emotions, Wieland restricts his readings to the same few passages and ignores any other that might interject with his original interpretation. His fears of doubting or questioning the truth of these religious tracts prompt him to develop an obscure and fanatical viewpoint. Clara describes his transformation as follows, “

His construction of the text were hasty and formed on a narrow scale. Everything was viewed in a disconnected position. One action and one precept were not employed to illustrate and restrict the meaning of the other...he labored to keep the sentiment of fear, and belief of the awe-creating presence of the Deity. Ideas foreign to this were sedulously excluded; to suffer their intrusion was a crime against the Divine Majesty" (Brown 9-10).

Wieland's radical emotions and dramatic approach to religion makes him vulnerable to the charge of enthusiasm. His "hasty" construction of the texts indicates his lack of common sense and rationality. As Clara notes, her father comes to equate doubt with $\sin$. Unwilling to examine the logic behind his newfound faith, Wieland arrives at problematic and misleading conclusions regarding his experiences.

Even more importantly, we must examine the significance that Wieland places on emotions, particularly that of fear and astonishment. As his religious vocation becomes more of an intricate part of his life, Wieland begins to experience feelings of anxiety, guilt, and extreme fear. Clara describes her father as undergoing an abrupt change in which his overzealous attitude changes into a fearful state of mind. She recalls, Suddenly the sadness that constantly attended him was deepened. Sighs and even tears, sometimes escaped him. To the expostulation of his wife, he seldom answered anything. When he designed to be communicative, he hinted that his 
peace of mind was flown, in consequence of deviation from his duty. A command had been laid upon him, which he had delayed to perform. He felt as if a certain period of hesitation and reluctance had been allowed him, but that this period was passed. He was no longer permitted to obey. The duty assigned to him was transferred, in consequence of his disobedience, to another, and all that remained was to endure the penalty (Brown 14).

In the quote above, Wieland suggests that God has made direct contact with him and asked him to carry out a command. Unable to do so, Wieland enters a state of panic, fearing that he will be punished for his lack of obedience. The emotions that he experiences are of great sadness, as he worries that he will no longer be allowed to obey. Supporters of the revivalist movement would argue that such affections were a sign of a true spiritual conversion. After all, experiencing an emotional connection to the Divine was considered to be a crucial aspect of spirituality. On the other hand, opponents of the Great Awakening maintained that extreme emotions (such as the ones that Wieland exhibits) were indicators of false conversions or misinterpreted episodes. Critics of the Revivalist movement argued that God worked in logical and reasonable ways thereby condemning enthusiasts for their impromptu and overly emotional experiences (Lovejoy 187). Given these contradictory points of view, Wieland's outburst of emotions can be attributed to either a true spiritual awakening or sheer enthusiasm.

The question as to whether Wieland's experiences are a byproduct of his enthusiasm or a manifestation of divine revelation is further complicated by his sudden and mysterious death. After spending many evenings in deep contemplation, Wieland announces to his family the nearing of a great misfortune. In noting that her father's 
behavior was unlike anything that she had seen before, Clara prepares the reader for the strange chain of events that are to follow. Feeling distraught and resigned, Wieland retreats to his temple to await his divine punishment. The family suddenly hears a loud explosion which is followed by a bright spark. Upon arriving to the scene of the accident Clara's uncle finds no signs of a fire yet he discovers Wieland's body lying naked and completely scorched. He notes, "his clothes had been removed, and it was not immediately perceived that they were reduced to ashes. His slipper and his hair were untouched" (Brown 19). The improbability of this event suggests that Wieland was the victim of a supernatural force. The undeniable physical proof serves to support the argument that Wieland experienced some form of spiritual awakening. His ability to forecast his own death, proposes that Wieland did indeed make contact with a divine entity.

On the other hand, the lack of a first-person account leaves the reader wondering whether the event was induced by Wieland. His previous tendencies to exhibit irrational and enthusiastic behavior prompt the reader to see Wieland as a perpetrator rather than a victim. In other words, without a trustworthy testimony the reader could easily come to the conclusion that Wieland's death was self-imposed. At this point in the narrative, Wieland's death can either be interpreted as an act of spontaneous combustion or as a suicide attempt. Clara wonders whether the event was "a fresh proof that the Divine Ruler interferes in human affairs, mediates an end, selects and commissions his agents, and enforces by unequivocal sanctions, submission to his will. Or, was it merely the irregular expansion of the fluid that imparts warmth to our hearts and our blood, caused by the fatigue of the preceding day, or flowing, by established laws, from the condition of 
his thoughts"? (Brown 21) Much like Clara, the reader is left to judge the validity of the events. In creating this mirroring effect, Brown highlights the tension that exists between divine revelation and enthusiasm. Unable to discern one form the other, the reader realizes the problems that arise when trying to distinguish one from the other.

\section{Supernatural Occurrences and Misinterpreted Experiences}

Similar issues regarding enthusiasm and supernatural entities are raised throughout Hogg's novel. In Confessions of a Justified Sinner, the reader is asked to either condemn Wrinhim of being an immoral and delusional character or to look upon him as a victim of supernatural forces. From the beginning of the narrative, Wrinhim is described as a temperamental young man who engages in immoral and heinous crimes. However, his predisposition to these actions is contradicted by his undying faith in the doctrine of Johannes Agricola. Wrinhim finds himself in a constant battle with his desire to sin and his longing to repent. His inability to refrain from leading a just and morally upright life, leads him to enter a state of desperation regarding the future of his eternal soul. He writes,

My heart quaked with terror when I thought of being still living in a state of reprobation, subjected to the awful issues of death, judgment, and eternal misery by the slightest accident or casualty, and I set about the duty of prayer myself with the utmost earnestness. I prayed three times every day, and seven times of the Sabbath (Hogg 91).

However, Wrinhim's proposed solution fails to produce a long-term effect on his behavior. His malicious thoughts and evil nature dominate his attempts to repent. As a result, this vicious cycle of sinning and repenting can either be interpreted as evidence of 
a spiritual awakening or as an indicator of Wrinhim's deteriorating mental state. Typically, individuals undergoing a religious conversion experience doubts regarding their faith, transgressions, and yearn to learn more about their religion. Throughout the 18th-century, Calvinist preachers such as Jonathan Edwards maintained that a spiritual awakening was a process like any other which involved trial and error. If applied to Wrinhim, his experiences resemble that of a legitimate conversion. On the other hand, it could be argued that Wrinhim uses religion to masque his morbid intentions. Unlike an individual who undergoes a spiritual conversion, Wrinhim's remorse comes across as superficial. The delight that he experiences from sinning also reinforces the idea that Wrinhim might be a delusional character. Wrinhim consciously increases prayer so as to ensure his salvation. His prayer and religious vocation appear to be more of a chore than a genuine impulse. The duality between these two contentions reveal that like Wieland, Wrinhim's experiences are not easily deciphered. The equal amounts of supporting evidence for each allegation reveals that it is both difficult (if not impossible) to arrive at a conclusion with certainty.

After many years of suffering from spiritual torment, Wrinhim is finally assured of his election. However, Wrinhim's news does come in the form of a spiritual awakening from within rather the decision is made by his Reverend father. He recalls, My reverend father one morning arose from his seat, and, meeting as I entered the room, embraced me, and welcomed me into the community of the just upon earth. I was struck speechless, and could make no answer to save by looks of surprise. Then each of them took me by a hand and my reverend father explained to me how he had wrestled with God, as the patriarch of old had done, not for a night, 
but for days and years, and that in bitterness and anguish of spirit, on my account; but he had at last prevailed, and how now gained the long and earnestly desired assurance of my acceptance with the Almighty (Hogg 105).

Once again, the reader is given permission to interpret these events as a valid sign of God's power or as a misinterpretation in part from the Wieland family. If it is assumed that Wrinhim's election was predestined then there is enough theological support to argue that this is a valid possibility. Unable to interpret the symptoms himself, Wrinhim depends on his father's expertise to make a respectable decision. As a priest, Wrinhim's father has the authority to confirm the nature of his son's experience. Acting as a mediator between God and his son, Wrinhim's father waits for a revelation. Nevertheless, Wrinhim's election could also be read as a forgery. His reaction to the news is that of surprise, indicating that he was not expecting to be granted salvation. The bureaucracy of this significant moment prompts the reader to question both the validity and supremacy of this decision. As the quote reveals, it was Wrinhim's reverend father who had to struggle with God's decision. Wrinhim's lack of participation in the transformation is presented as a worrisome.

Wrinhim's experiences become even more problematic when he encounters Gil Martin, a character who further compromises the validity of Wrinhim's experiences. Suspected of being a doppelganger, Gil's presence only aggravates Wrinhim's desire to sin and to stray from the path of righteousness. A self-pronounced messenger of God, Gil convinces Wrinhim to obey his commands and to take advantage of his privileged status. Gil argues that as a justified individual, no good deeds or wrongdoings could alter God's sovereignty. In doing so, Gil pushes Wrinhim to commit horrible crimes such as murders 
and rape. His shape shifting and mind-reading abilities make him an admirable character in the eyes of Wrinhim. In possessing these supernatural powers, Wrinhim receives Gil with respect and loyalty. However, Wrinhim's occult friendship with Gil challenges both Wrinhim's ability to reason and the state of his mental faculties. Throughout the narrative, Wrinhim holds meetings with Gil in secluded places so as to avoid any eavesdropping of their conversation. Gil's company is rarely witnessed by anyone other than Wrinhim, creating more of air of mystery surrounding his existence. As a result of these strange coincidences, Gil's character can either be seeing as a figment of Wrinhim's imagination or as a menacing supernatural entity.

The tension between these two possibilities is clearly depicted in one of the earlier scenes in which Wrinhim is accused of stalking his step-brother George. The townspeople describe the persecution in the following manner,

George found it every day more and more necessary to adhere to this system of seclusion; for it was not alone the hisses of the boys and populace that pursued him - a fiend of more malignant aspect was ever at his elbow, in the form of his brother. To whatever place of amusement he betook himself, as however well he concealed his brother Wrinhim also, always within a few yards of him, generally about the same distance, and ever and anon darting looks at him that chilled his very soul (Hogg 34).

From the perspective of the townspeople, Wrinhim is clearly guilty of pursuing his brother at all times. The physical proof is overwhelming as it happens to coincide with Wrinhim's feelings of hatred towards his brother. However, Wrinhim's rendition of the 
events is quite different. Claiming to have been ill and bedridden at the time of the incidents, Wrinhim refuses to accept blame. He explains,

For a month I saw no one but such as came into my room, and, for all that, it will be seen that there were plenty of the same set to attest upon oath that I saw my brother every day during this period; that I persecuted him with my presence day and night, while all the time I never saw his face save in a delusive dream. I cannot comprehend what maneuvers my illustrious friend was playing off with them about this time; for he, having the art of personating whom he chose, had peradventure decided them, else so many of them had never all attested to the same thing (Hogg 140).

The disparity between these accounts offer two possible solutions, either a) Wrinhim is delusional or b) Gil is truly responsible for these acts. Wrinhim's immoral behavior prior to meeting Gil suggests that he might be culpable of stalking his brother. The dislike and envy that Wrinhim feels towards his brother serve as more than probable cause for his actions. In using Gil as a scapegoat, Wrinhim is able to abscond from the allegations while simultaneously presenting himself as a victim. Interestingly, Wrinhim admits to seeing his brother in one of his "delusive dreams". In mentioning this, Wrinhim raises the possibility that he might be suffering from delusions. Unable to distinguish the imagination from reality, Wrinhim's recollection of events may be seen as flawed or unreliable. In the same way, it can be argued that Gil used his supernatural abilities to impersonate Wrinhim. Gil's plan to defame and destroy Wrinhim make him a suspect in this case. If Wrinhim's testimony is accepted as fact then one must assume that Gil did indeed take on the shape of Wrinhim to torment his brother. If this is the case then Gil 
becomes the antagonist and Wrinhim the innocent bystander. In providing multiple points of view to the same event, Hogg encourages the reader to question the possibility of arriving at a single truth. Both the townspeople and Wrinhim's testimonies can be interpreted as "truthful" however this does not mean that a single truth exists. Hogg prompts the reader to examine all possibilities before making any assumptions.

As the narrative draws to a close, Wrinhim loses the ability to discern his imagination from reality. Not only does this present him as an unreliable narrator but it also causes the reader to once again question his sanity. His relationship with Gil causes him to lose track of time, to confuse his actions for that of others, and to question his own existence. After being accused of several other crimes (the murder of his brother, stalking, raping a young girl, and embezzlement) Wrinhim finds himself in a desperate and deplorable state. Blaming Gil for all of his misfortunes, Wrinhim resolves to flee in hopes of avoiding any further harm. After many failed attempts at hiding, Wrinhim comes to the realization that he is unable to escape Gil's company. Gil's supernatural abilities enable him to tract Wrinhim regardless of how secretive or remote the location. The relationship which Wrinhim once viewed as privileged and divine quickly transforms into a curse. Gil proposes that they both take their own lives in order to put an end to their sufferings. At first, Wrinhim is adamant to accept this proposal but after reflecting on the "dreadful alternative" he agrees to commit suicide. He writes, "It was in vain that I reasoned on the sinfulness of the deed, and on its damming nature; he made me condemn myself out of my own mouth by allowing the absolute nature of justifying grace and the impossibility of the elect ever falling from the faith" (Hogg 212). Wrinhim acknowledges that self-destruction is an unredeemable sin yet he allows Gil to convince him otherwise. 
This final act can either be seen as a sign of Wrinhim's devotion to Gil or as an indicator of his madness. If Gil is to be considered a real character then the power that he has over Wrinhim is undeniable. His ability to convince Wrinhim to commit suicide confirms his wicked and immoral intention. By presenting the option as an ultimate test of his loyalty, Gil once again tricks Wrinhim into obeying. Another more cynical reading of the ending to this narrative is that Wrinhim commits suicide in order to escape his misery. Realizing that his actions are beyond repair, Wrinhim falls into a state of panic. Gil could have indeed been a figment of Wrinhim's imagination which in turn allowed him to continue to sin without regret.

Like Wieland's Wrinhim's encounter with the supernatural ultimately leads to his death. Both of their deaths are unresolved, leaving the reader to judge whether they were acts of self-destruction or manifestations of the supernatural. By posing this ambiguity, Brown and Hogg force the reader out of the comforts of predictable or tidy endings. The ambiguity and dark portrayals of religion in these novels propose that the distinction between enthusiasm and divine revelation is not always a clear one. 


\section{CONCLUSION}

One cannot read the novels of Charles Brockden Brown and James Hogg without noticing the emphasis that is placed on religion and the imagination. In Wieland religion is depicted as a dangerous force that has the ability to seduce and transform individuals. Wieland's willingness to submit combined with his desire to obey suggest that religion requires one to relinquish autonomy. Hogg displays a similar viewpoint to that of Brown's by scrutinizing the validity of a spiritual awakening. In fact, Hogg comments on the hypocritical nature of religion by presenting Gil as a demented character who misuses his justified state to sin without measure. The striking similarities between enthusiasm and authentic religious experiences raise the question whether it is truly possible to distinguish one from the other. However, the reader is not meant to dwell on this question for any extended amount of time. Rather, the Gothic novel beckons the reader to move beyond the concepts of single truths and decipherable experiences. By ending their narratives in a convoluted and inconclusive manner, Brown and Hogg restore authority to the reader. Whether the reader decides to condemn Wieland and Wrinhim for their immoral acts or to view them as victims of circumstances is irrelevant. Individual interpretation becomes a choice that only the reader can make. As Brown cleverly remarks in the advertisement to his book, "Whether this tale will be classed with the ordinary and frivolous sources of amusement, or be ranked with the few productions whose usefulness secures to them a lasting reputation, the reader must be permitted to decide" (Brown 3). 


\section{BIBLIOGRAPHY}

Brown, Charles Brockden, Jay Fliegelman. Wieland; and Memoirs of Carwin the Biloquist. Penguin classics. New York, N.Y., U.S.A. : Penguin Books, 1991.

Clery, E. J. The Rise of Supernatural Fiction: 1762-1800. Cambridge, England: Cambridge UP, 1999. MLA International Bibliography. EBSCO. Web. 7 Sept 2009.

Gamer, Michael. Romanticism and the Gothic: Genre, Reception, and Canon Formation. Cambridge studies in Romanticism, 40. Cambridge [England: Cambridge University Press, 2000. Internet resource.

Hogg, James. The Private Memoirs and Confessions of a Justified Sinner. New York: Norton, 1970.

Hume, Robert D. "Gothic versus Romantic: A Revaluation of the Gothic Novel." PMLA: Publications of the Modern Language Association of America 84.2 (1969): 282290. MLA International Bibliography. EBSCO. Web. 10 Aug. 2009.

Looby, Christopher. Voicing America: Language. Literary Form. and the Origins of the United States. Chicago: University of Chicago Press, 1996.

Lovejoy, David S. Religious Enthusiasm in the New World: Heresv to Revolution. Cambridge, Mass: Harvard University Press, 1985.

Manly, William M. "The Importance of Point of View in Brockden Brown's Wieland." American Literature: A Journal of Literary History, Criticism, and Bibliography 35.3 (1963): 311-321. MLA International Bibliography. EBSCO. Web. 6 June. 2009.

Miles, Robert Gothic Writing 1750-1820: A Genealogy. London: Routledge, 1993. MLA International Bibliography. EBSCO. Web. 18 May. 2009.

Mogen, David, Scott Patrick Sanders, and Joanne B. Karpinski. Frontier Gothic: Terror and Wonder at the Frontier in American Literature. Rutherford, N.J.: Fairleigh Dickinson University Press, 1993.

Phillip, Adams, and Edmund Burke. A Philosophical Enquiry into the Origin of our Ideas of the Sublime and Beautıful. New York: Oxford U. P, 1998. Print.

Price, Fiona "'Myself Creating What I Saw': The Morality of the Spectator in EighteenthCentury Gothic." Gothic Studies 8.2 (2006): 1-17. MLA International Bibliography. EBSCO. Web. 2 June 2009. 
Redekop, Magdalene "Beyond Closure: Buried Alive with Hogg's Justified Sinner." ELH 52.1 (1985): 159-184. MLA International Bibliography. EBSCO. Web. .22 Sept 2009.

Sedgwick, Kosofsky Eve. The Coherence of Gothic Conventions. New York. New York: Methuen Inc, 1986.

Trainer, James, and Clara Reeve. The Old English Baron: A Gothic Story. English novels. London: Oxford U. P, 1967. Print.

Voloshin, Beverly R. "Wieland: 'Accounting for Appearances'." New England Quarterly: A Historical Review of New England Life and Letters 59.3 (1986): 341-357. MLA International Bibliography. EBSCO. Web. 13 May. 2009.

Watt, James. Contesting the Gothic Fiction. Genre and Cultural Conflict, 1764-1832. Cambridge studies in Romanticism, 33. Cambridge: Cambridge University Press, 1999. 